\title{
Dual Pharmacological Targeting of HDACs and PDE5 Inhibits Liver Disease Progression in a Mouse Model of Biliary Inflammation and Fibrosis
}

\author{
Alex Claveria-Cabello ${ }^{1}\left(\right.$, Leticia Colyn ${ }^{1}{ }^{(}$, Iker Uriarte ${ }^{1,2}{ }^{(0}$, Maria Ujue Latasa ${ }^{1}$, \\ Maria Arechederra 1,3 (D), Jose M. Herranz 1,2 (D), Laura Alvarez ${ }^{1}$, Jesus M. Urman ${ }^{3,4}$, \\ Maria L. Martinez-Chantar 2,5 ${ }^{\mathbb{D}}$, Jesus M. Banales ${ }^{2,6,7}$, Bruno Sangro ${ }^{2,3,8}$, Krista Rombouts 9 (D), \\ Julen Oyarzabal ${ }^{10}$, Jose J. G. Marin ${ }^{2,11}$ (D), Carmen Berasain 1,2,3,+(D), Matias A. Avila $1,2,3, *,+(\mathbb{D})$ \\ and Maite G. Fernandez-Barrena $1,2,3, *,+(\mathbb{D}$ \\ 1 Program of Hepatology, Center for Applied Medical Research (CIMA), University of Navarra, \\ 31008 Pamplona, Spain; aclaveria.1@alumni.unav.es (A.C.-C.); lcolyn@alumni.unav.es (L.C.); \\ iuriarte@unav.es (I.U.); mulatasa@unav.es (M.U.L.); macalderon@unav.es (M.A.); \\ jmherranzalzueta@gmail.com (J.M.H.); lalvarez5@unav.es (L.A.); cberasain@unav.es (C.B.) \\ 2 National Institute for the Study of Liver and Gastrointestinal Diseases (CIBERehd, Carlos III Health \\ Institute), 28029 Madrid, Spain; mlmartinez@cicbiogune.es (M.L.M.-C.); \\ jesus.banales@biodonostia.org (J.M.B.); bsangro@unav.es (B.S.); jjgmarin@usal.es (J.J.G.M.) \\ 3 IdiSNA, Navarra Institute for Health Research, 31008 Pamplona, Spain; jm.urman.fernandez@navarra.es \\ 4 Department of Gastroenterology and Hepatology, Navarra University Hospital Complex, \\ 31008 Pamplona, Spain \\ 5 Liver Disease Laboratory, Center for Cooperative Research in Biosciences (CIC bioGUNE), Basque Research \\ and Technology Alliance (BRTA), Bizkaia Technology Park, 48160 Derio, Spain \\ 6 Department of Liver and Gastrointestinal Diseases, Biodonostia Health Research Institute, \\ Donostia University Hospital, 20014 San Sebastian, Spain \\ 7 IKERBASQUE, Basque Foundation for Science, 48013 Bilbao, Spain \\ 8 Hepatology Unit, Department of Internal Medicine, University of Navarra Clinic, 31008 Pamplona, Spain \\ 9 Institute for Liver and Digestive Health, University College London, London NW3 2PF, UK; \\ k.rombouts@ucl.ac.uk \\ 10 Program of Molecular Therapeutics, Center for Applied Medical Research (CIMA), University of Navarra, \\ 31008 Pamplona, Spain; julenoyarzabal@external.unav.es \\ 11 Experimental Hepatology and Drug Targeting (HEVEPHARM), University of Salamanca, \\ Biomedical Research Institute of Salamanca (IBSAL), 37007 Salamanca, Spain \\ * Correspondence: maavila@unav.es (M.A.A.); magarfer@unav.es (M.G.F.-B.) \\ + These authors are co-senior authors of this study.
}

Received: 1 December 2020; Accepted: 10 December 2020; Published: 13 December 2020

Simple Summary: Chronic liver injury and inflammation leads to excessive deposition of extracellular matrix, known as liver fibrosis, and the distortion of the hepatic parenchyma. Liver fibrosis may progress to cirrhosis, a condition in which hepatic function is impaired and most cases of liver tumors occur. Currently, there are no effective therapies to inhibit and reverse the progression of liver fibrosis, and therefore, chronic liver disease remains a global health problem. In this study we have tested the efficacy of a new class of molecules that simultaneously target two molecular pathways known to be involved in the pathogenesis of hepatic fibrosis. In a clinically relevant mouse model of liver injury and inflammation we show that the combined inhibition of histones deacetylases and the cyclic guanosine monophosphate (cGMP) phosphodiesterase phosphodiesterase 5 (PDE5) results in potent anti-inflammatory and anti-fibrotic effects. Our findings open new avenues for the treatment of liver fibrosis and therefore, the prevention of hepatic carcinogenesis.

Abstract: Liver fibrosis, a common hallmark of chronic liver disease (CLD), is characterized by the accumulation of extracellular matrix secreted by activated hepatic fibroblasts and stellate cells 
(HSC). Fibrogenesis involves multiple cellular and molecular processes and is intimately linked to chronic hepatic inflammation. Importantly, it has been shown to promote the loss of liver function and liver carcinogenesis. No effective therapies for liver fibrosis are currently available. We examined the anti-fibrogenic potential of a new drug (CM414) that simultaneously inhibits histone deacetylases (HDACs), more precisely HDAC1, 2, and 3 (Class I) and HDAC6 (Class II) and stimulates the cyclic guanosine monophosphate (cGMP)-protein kinase G (PKG) pathway activity through phosphodiesterase 5 (PDE5) inhibition, two mechanisms independently involved in liver fibrosis. To this end, we treated Mdr2-KO mice, a clinically relevant model of liver inflammation and fibrosis, with our dual HDAC/PDE5 inhibitor CM414. We observed a decrease in the expression of fibrogenic markers and collagen deposition, together with a marked reduction in inflammation. No signs of hepatic or systemic toxicity were recorded. Mechanistic studies in cultured human HSC and cholangiocytes (LX2 and H69 cell lines, respectively) demonstrated that CM414 inhibited pro-fibrogenic and inflammatory responses, including those triggered by transforming growth factor $\beta$ (TGF $\beta$ ). Our study supports the notion that simultaneous targeting of pro-inflammatory and fibrogenic mechanisms controlled by HDACs and PDE5 with a single molecule, such as CM414, can be a new disease-modifying strategy.

Keywords: liver fibrosis; hepatobiliary carcinogenesis; histone deacetylases; cGMP phosphodiesterase inhibitor; HDAC inhibitor; precision medicine

\section{Introduction}

Liver fibrosis, characterized by excessive accumulation of extracellular matrix (ECM) components, is the principal event that contributes to most of the complications of chronic liver diseases (CLDs), and represents an important and underestimated global health problem [1,2]. The progression of CLD is usually a longstanding process, as many liver pathologies develop, on average, after 15-20 years of chronic parenchymal injury [3]. Epidemiological studies have estimated that more than 800 million individuals worldwide are affected by a form of CLD, with a mortality rate of two million deaths per year [4-7]. The most relevant etiologies leading to CLD comprise chronic infection by hepatitis $B$ and $\mathrm{C}$ viruses (HBV and HCV), non-alcoholic fatty liver disease (NAFLD), excess ethanol consumption, autoimmune diseases, including conditions affecting the biliary tree such as primary biliary cholangitis (PBC), and primary sclerosing cholangitis (PSC), autoimmune hepatitis (AIH), and rare hereditary diseases such as Wilson's disease, $\alpha 1$-anti-trypsin deficiency, or hemochromatosis $[4,5,8]$.

The main event from the beginning of CLD is hepatocellular death that triggers an inflammatory reaction. This process is linked to a potent regenerative response in order to restore the lost hepatic tissue. In the context of acute or self-limited damage, this inflammatory and wound-healing response is transient, and the liver architecture is restored to the normal stage. However, under chronic injury, this response is sustained, leading to the accumulation of ECM and the progressive substitution of liver parenchyma by scar tissue. Persistent inflammation and fibrosis, together with the presence of regenerative nodules of hepatocytes, are hallmarks of liver cirrhosis. The cirrhotic state is also characterized by hepatocellular dedifferentiation and the loss of parenchymal function [9]. In this context is where most cases of primary liver cancer, mainly hepatocellular carcinoma (HCC) but also cholangiocarcinoma (CCA), develop and therefore, liver cirrhosis is considered a pre-neoplastic condition $[8,10,11]$.

Activated myofibroblasts are considered the critical effectors of fibrosis development, representing a spectrum of ECM-producing cells that mainly derive from hepatic stellate cells (HSC) and portal fibroblasts $[12,13]$. Following liver injury, these cells acquire a phenotype characterized by the loss of retinoid droplets and contractile activity, increased proliferation, production of ECM, and the release of pro-inflammatory, pro-fibrogenic, and pro-mitogenic cytokines. Myofibroblast trans-differentiation 
is, therefore, a highly conserved and tightly regulated process where coordinated cellular changes result from either activating events as well as from the loss of repressive signaling [14,15]. A chronic inflammatory response is critically sustained during CLD progression [16]. Liver cells death and inflammation initiates fibrogenesis activating myofibroblasts and resident liver macrophages (Kupffer cells), and by recruiting monocytes and other immune cells from peripheral blood. The release of several soluble peptide mediators (cytokines, growth factors, and chemokines) and reactive oxygen species (ROS) generation influence the trafficking of inflammatory and immune cells within the liver. Therefore fibrosis progression is the net result of many diverse and regulated actions [17].

Despite significant advances in the understanding of the cellular and molecular mechanisms of liver fibrogenesis, no effective pharmacological therapies have reached the clinical practice yet [2]. To date, the most effective therapy is to remove the causative agent (e.g., eliminating viral infection or stopping alcohol consumption), or, in the case of advanced stages, liver transplantation [18,19]. This situation highlights the urgent need for new approaches to identify effective therapeutic strategies.

We and others have previously demonstrated that epigenetic events are fundamental in myofibroblast activation and functions [20-22]. The term epigenetics describes reversible mechanisms controlling gene expression that can be inherited through cell division and that do not involve alterations to the underlying DNA sequence. Epigenetics includes at least three mechanisms: DNA methylation, histone modifications, and non-coding RNA (ncRNA) mediated gene regulation [23]. The modulation of gene expression is not only important for myofibroblasts activation, but also for their ability to respond to microenvironmental cues and their persistence in CLD up to cancer development [21,24]. Histone acetylation is one of the most studied epigenetic events, a reversible process closely linked to gene transcriptional activation, while histone deacetylation consistently results in gene transcriptional repression [25]. The balance between the acetylated and deacetylated states of histones is controlled by the antagonistic actions of two types of enzymes: Histone acetyltransferases (HATs) and histone deacetylases (HDACs) [26]. HDACs have emerged as crucial transcriptional regulators in diverse physiological aspects of liver fibrosis [27]. Members of the HDAC superfamily have been classified according to their sequence features and domain organization. Class I HDACs, including HDAC1, 2, 3, and 8, are ubiquitously expressed and reside in the nucleus while Class II HDACs (HDAC4, 5, 6, 7, 9, and 10) are cell-type specific and able to shuttle between cytoplasm and nucleus. Class III HDACs, which are structurally and enzymatically distinct, are named sirtuins (SIRT 1-7), present different localizations including the nucleus, cytoplasm, or mitochondria, and finally, Class IV HDACs, composed only by HDAC11, localizes to the nucleus and shares sequence homology with the catalytic domains of Class I and II HDACs [28]. It has been demonstrated that the inhibition of Class I and II HDACs leads to a noticeable reduction of HSC activation and proliferation [29], and the induction of apoptosis and autophagic cell death of activated HSCs [30]. These HDACs also participate in the regulation of transforming growth factor $\beta$ (TGF $\beta$ ) signaling, a key fibrogenic pathway, and of diverse inflammatory responses [27]. Moreover, it has been well established how specific HDACs catalyze the deacetylation of many non-histone proteins, thus being able to affect other different cellular processes besides gene transcription [31], as is the case of HDAC6. HDAC6 localizes predominantly to the cytoplasm, it is structurally and functionally unique, distinguishing itself from other family members in that it contains two HDAC domains and a ubiquitin-binding motif, the BUZ finger [32]. HDAC6 regulates microtubule function and stability via $\alpha$-tubulin deacetylation [33,34], one of its best-characterized substrates, and controls cell growth [35], inflammatory events [36,37], and fibrogenic mechanisms [38-40]. HDAC inhibitors (HDACi) have become promising drug candidates, presenting pleiotropic anti-fibrogenic properties depending on their potency and specific activity against the different classes of HDACs [27,41]. Several non-selective HDACi have been approved by the Food and Drug Administration (FDA) as antitumor agents [42,43]. However, many of them harbor undesired side effects, including a marked hepatotoxicity [44], so none of them are currently under investigation for liver fibrosis. Therefore, targeting specific HDACs with higher selectivity and 
a better understanding of the role of each isozyme could lead the generation more effective and less toxic therapeutic agents for this condition.

Another interesting group of compounds that has recently shown promising anti-fibrogenic properties is that of phosphodiesterase 5 inhibitors (PDE5i) [45,46]. PDE5i are already approved for the treatment of erectile dysfunction [47], lower urinary tract disorders, and pulmonary arterial hypertension [48]. Phosphodiesterase 5 (PDE5) acts by hydrolyzing the phosphodiester bond of the second messenger cyclic guanosine monophosphate (cGMP), converting it to the inactive GMP. PDE5 inhibition thus results in increased intracellular levels of cGMP and the activation of downstream signaling cascades, including protein kinase G (PKG)-mediated signaling. Synthesis of cGMP is catalyzed by the intracellular soluble guanylate cyclase (sGC), which can be activated by NO binding [49]. It has been observed that in liver fibrosis exists a profound perturbation of the NO-sGC-cGMP signaling axis. This is due in part to a defective availability and responsiveness to NO by activated HSC cells. NO can be depleted by increased ROS levels or the impaired expression of enzymes implicated in its synthesis, such as endothelial NO synthase (NOS) [50,51], while its cellular effects may be dampened by reduced expression of PKG [52]. In this sense, strategies directed to increase intracellular cGMP levels through the use of PDE5i as well as sGC stimulators are demonstrating potent anti-inflammatory and anti-fibrogenic properties [53-55].

Based on all these observations, we hypothesized that simultaneous interference with the enzymatic activities of HDACs and PDE5 could be a potential strategy to halt fibrosis progression. Therefore, we tested the effects of CM414, a recently developed first-in-class small-molecule with moderate inhibitory activity against Class I HDACs but a potent inhibitor of HDAC6 and PDE5 (Figure 1). CM414 was originally conceived to be applied in the context of neurological pathologies such as Alzheimer disease [56]. Previous studies revealed that the co-administration of sub-effective doses of a PDE5i together with vorinostat, an HDACi, produced a synergistic effect on the induction of epigenetic responses (i.e., increased H3K9Ac levels) and prevented neurodegenerative events [57]. These findings suggested that pathways affected by these two inhibitors could functionally interact at some point in the regulation of gene expression. CM414 has an acceptable therapeutic window in vitro and in vivo, with no evidences of toxicity observed [56,58].

(a)

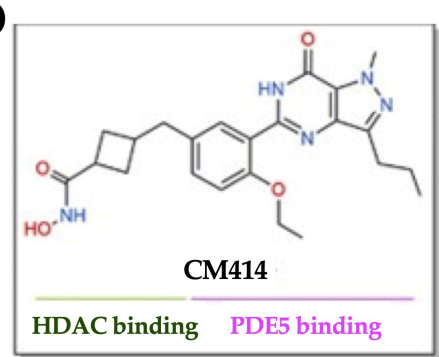

(b)

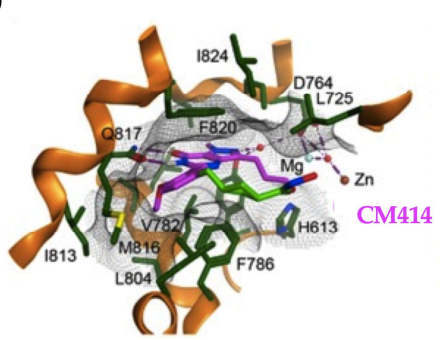

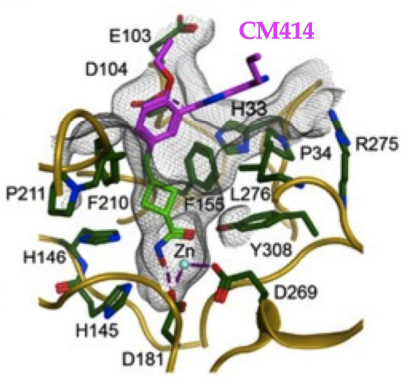

Figure 1. CM414, dual inhibitor of Class I histone deacetylases (HDACs) and phosphodiesterase 5 (PDE5). (a) CM414 chemical formula highlighting the hydroxamic moiety that interacts with HDACs and the pyrazolopyrimidinone core that interacts with PDE5. (b) representations of CM414 bound to PDE5 (left panel) and HDAC2 (right panel).

To investigate the potential anti-fibrogenic effects of CM414, we used a clinically relevant animal model of chronic portal inflammation and bile duct proliferation with progression to liver fibrosis and cancer (Mdr2/Abcb4-deficient mice (Mdr2-KO)). Mdr2-KO mice lack the ABC protein Mdr2, a phosphatidylcholine transporter, which results in impaired phospholipid biliary secretion. The absence of phospholipids able to neutralize the detergent activity of bile acids leads to an unspecific attack to the canalicular and ductular membranes resulting in bile regurgitation into the portal tracts [59], cell death, and portal inflammation [60,61]. All these effects appear in Mdr2-KO mice already within the first week of age, accompanied by an increase in serum transaminases levels and followed by enhanced ECM 
deposition and progression to fibrosis [62]. As a consequence of chronic inflammation and fibrosis, Mdr2-KO mice have been shown to develop HCC within 12-15 months of age [63].

Using this model of CLD, here we show that CM414 administration was able to attenuate liver injury and inflammation and to inhibit the progression of CLD in Mdr2-KO mice with established fibrosis without apparent toxicity. Mechanistic studies identified different and cooperative actions of CM414 resulting from the simultaneous inhibition of Class I HDACs, HDAC6, and PDE5.

Together, our findings indicate that CM414 may represent an excellent example of developing new anti-fibrogenic and cancer preventive strategies based on multitargeted drugs with anti-inflammatory and anti-fibrogenic properties. This work may pave the way for future treatments of fibrosis, a condition that not only affects the liver as it also occurs in other organs like the lung and kidney, with dramatic consequences.

\section{Results}

\subsection{In Vivo Evaluation of the Anti-Fibrogenic Potential of CM414, a Dual HDAC-PDE5 Inhibitor}

Mdr2-KO mice are a widely accepted and clinically relevant genetic mouse model of liver fibrosis and carcinogenesis [61,63]. By two months of age, these mice already display a significant degree of periportal fibrosis in an environment of ongoing liver injury and inflammation [64]. To test our dual HDAC and PDE5 inhibitor, we chose to use older mice with a more advanced stage of the disease to better mimic a therapeutic approach rather than a preventive strategy. First, we examined the expression of CM414 molecular targets in the livers from six-month-old Mdr2-WT and Mdr2-KO mice. Mdr2-KO mice showed significantly elevated expression levels of the Class I Hdac enzymes Hdac1, Hdac2, and Hdac3 in liver tissues as analyzed by qPCR. The expression of Hdac6 and Pde5 was also evaluated, and their mRNA levels were also significantly increased compared to those in healthy controls (Figure 2a). Next, we performed immunohistochemical staining of liver tissue samples from these mice. We detected the presence of HDAC1 in the nucleus of most hepatic cells, including activated myofibroblasts and cholangiocytes in Mdr2-KO mice (Figure 2b). HDAC6 showed cytoplasmic localization, whose abundance was markedly increased in cholangiocytes in $\mathrm{Mdr2}-\mathrm{KO}$ mice, but also in hepatocytes and myofibroblasts. In healthy livers, PDE5 protein was mainly expressed by perivenular hepatocytes and, to a lesser extent, by perisinusoidal cells. In contrast, in Mdr2-KO livers, hepatic staining of PDE5 increased significantly, particularly in cholangiocytes and fibrous septa (Figure $2 \mathrm{~b}$ ).

To evaluate the effects of CM414, six-month-old Mdr2-KO mice were treated with $40 \mathrm{mg} / \mathrm{kg}$ (i.p.) of the drug for 1 month as indicated (Figure 3a). CM414 administration was well tolerated, and treated animals gained similar weight as those administered with the corresponding vehicle (data not shown). We found a reduced liver to body weight ratio (Figure 3b) and improved aspartate aminotransferase (AST), alanine aminotransferase (ALT), and alkaline phosphatase (ALP) serum levels in the CM414 treated group (Figure 3c). As expected, six months-old-Mdr2-KO mice already presented advanced fibrosis as indicated by Sirius Red staining of crosslinked collagen in liver sections (Figure 3d). CM414 treatment markedly reduced collagen deposition compared with vehicle-treated Mdr2-KO control mice (Figure 3d). The high abundance of $\alpha$-SMA positive periductal cells found in Mdr2-KO mice [65] was also markedly reduced by CM414 treatment (Figure 3d). In response to the cholestatic injury, portal fibroblasts, which reside around the portal area and maintain the integrity of the biliary tree and portal tract, proliferate, get activated, and together with hepatic stellate cells, contribute to collagen type I deposition [66]. CD34, a marker of portal fibroblasts [62], was found highly expressed in control Mdr2-KO mice, predominantly in the portal and sinusoidal areas (Figure 3d). CD34 staining was markedly reduced in CM414-treated mice (Figure 3d). Ductular reaction, a cellular response associated with liver fibrosis and damage, and identified by CK19 staining, is commonly observed in Mdr2-KO mice [67]. We also observed a significant attenuation of this response in CM414-treated Mdr2-KO mice (Figure 3d). 
(a)

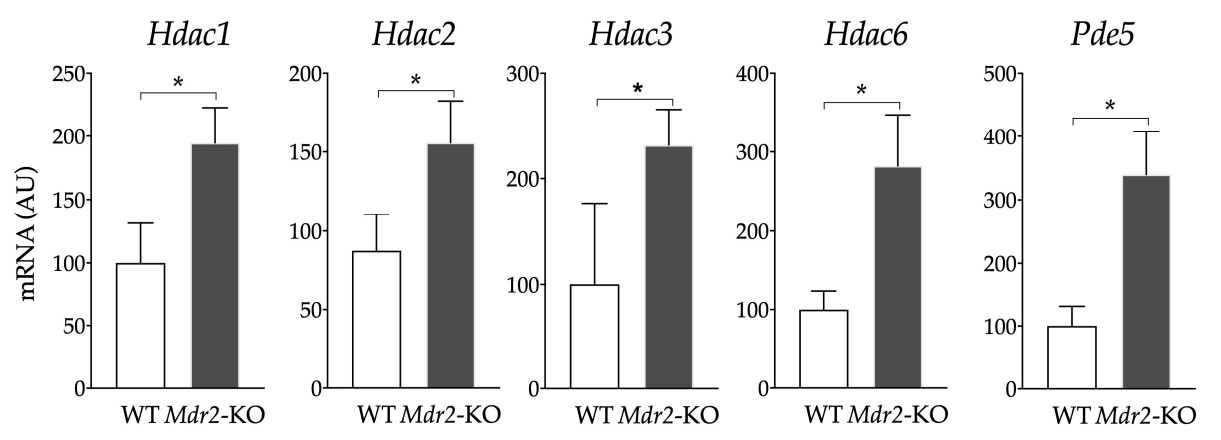

(b)
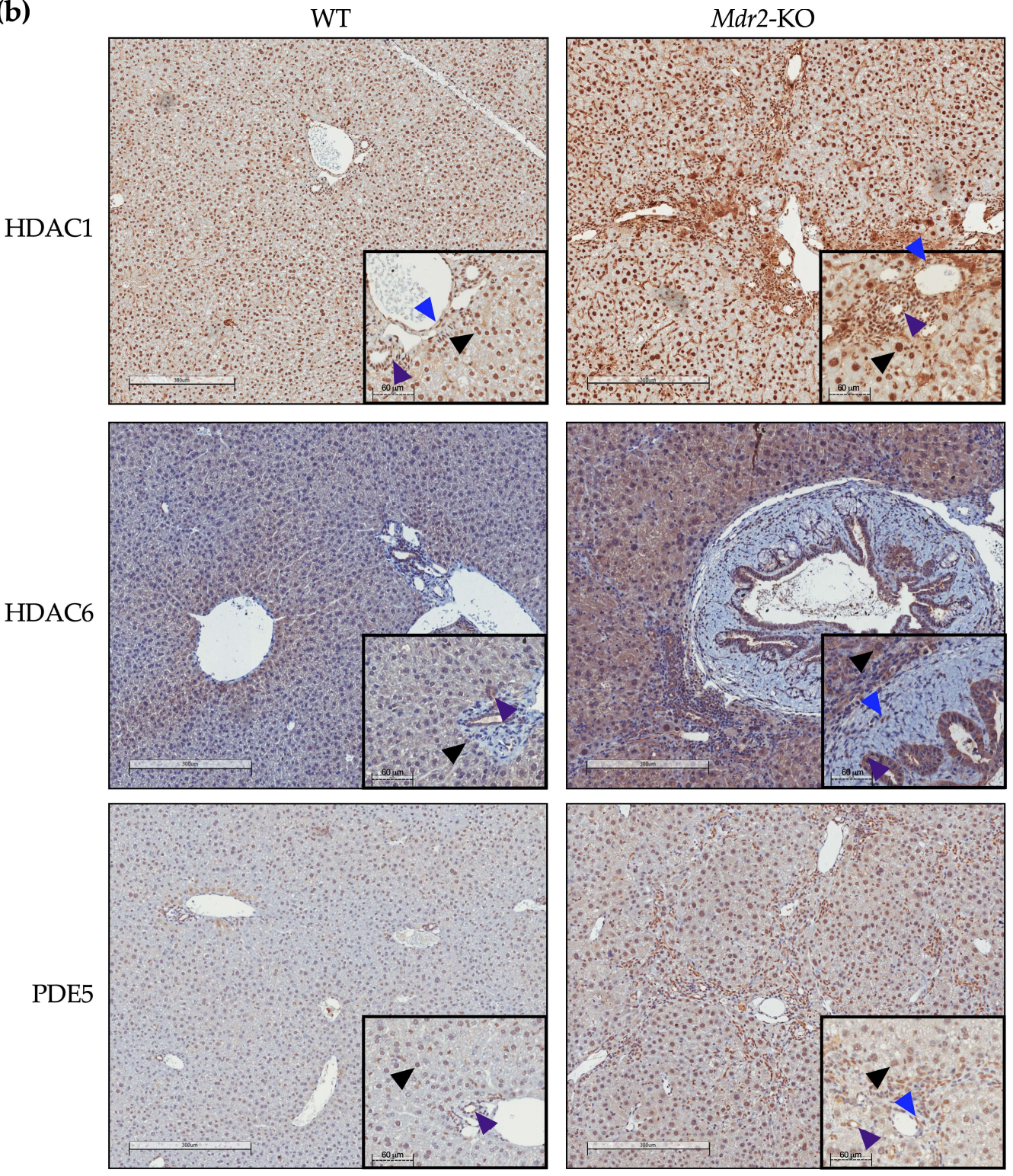

Figure 2. Expression of CM414 molecular targets in the livers of six-months old WT and Mdr2-KO mice. (a) qPCR analyses of Hdac1, Hdac2, Hdac3, Hdac6, and Pde5 mRNA levels. (b) representative images of HDAC1, HDAC6, and PDE5 immunostaining in livers from WT and Mdr2-KO mice. Insets show enlarged areas with arrowheads indicating positive staining in hepatocytes (black), fibrogenic cells (blue), or biliary cells (purple). ${ }^{*} p<0.05$. 
(a) Vehicle
CM414
Mdr2-KO
6 months

(d)
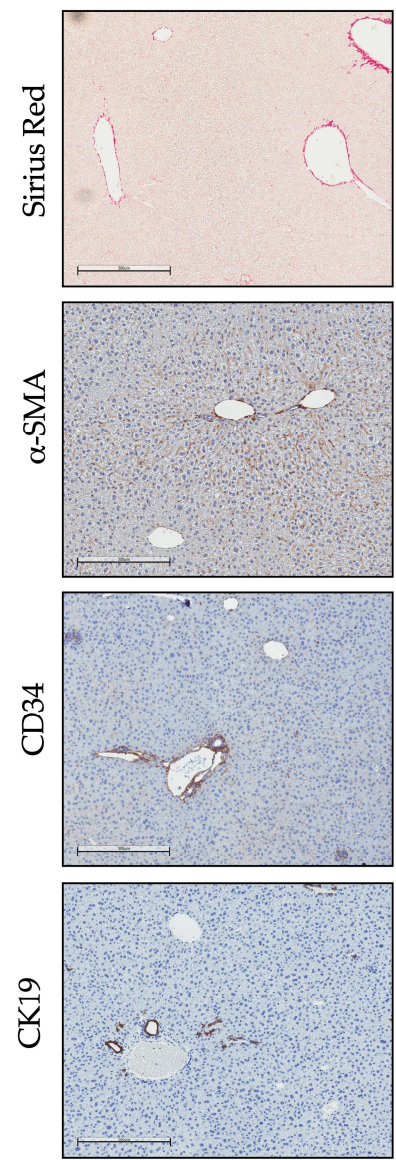

(b) Liver / Body

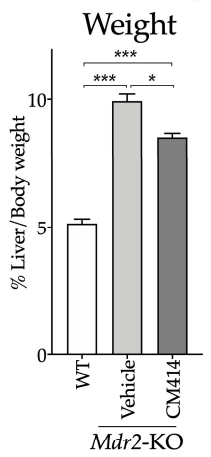

(c)

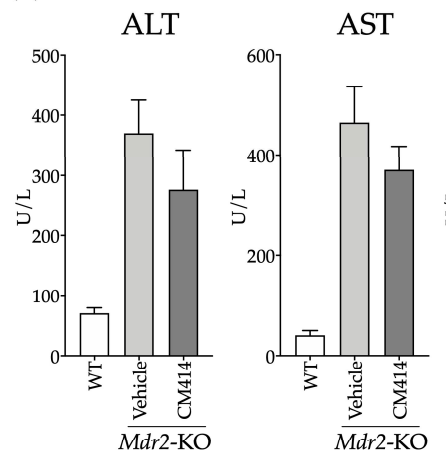

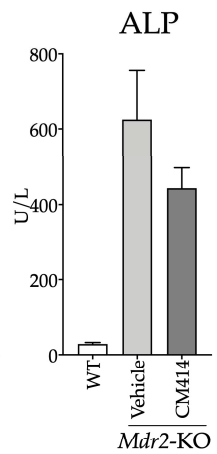

Mdr2-KO CM414
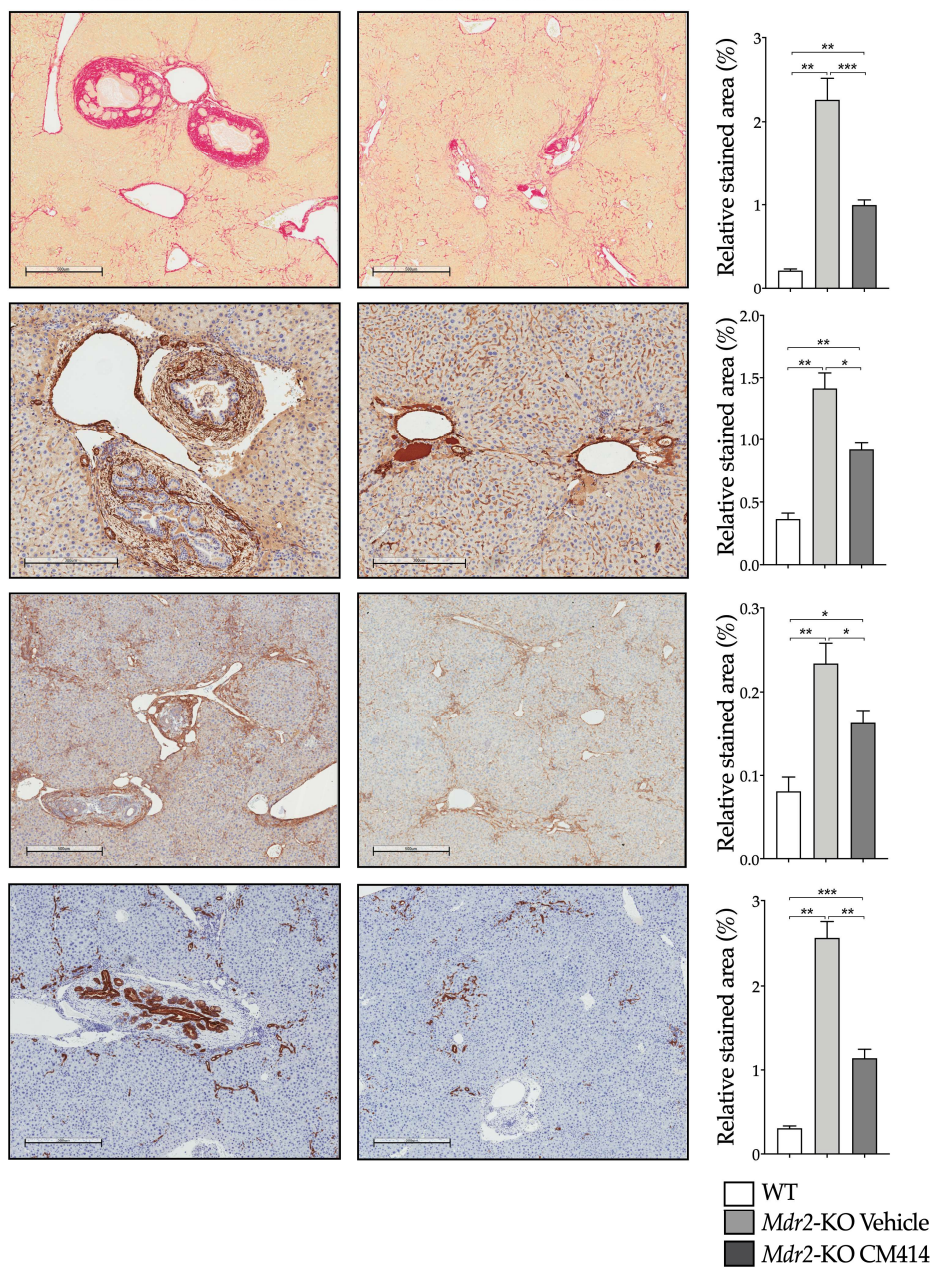

Figure 3. Effect of CM414 treatment on liver injury and fibrosis in $M d r 2-\mathrm{KO}$ mice. (a) aiagram showing the treatment schedule of $M d r 2-\mathrm{KO}$ mice. Animals received a daily i.p. injection of vehicle or CM414 ( $40 \mathrm{mg} / \mathrm{kg}$ body weight) five days per week for 4 weeks, when animals were sacrificed, and serum and liver tissue samples were analyzed. (b) liver-to-body weight ratio (expressed as \%) in WT mice and in Mdr2-KO mice treated with vehicle or CM414. (c) serum transaminases (alanine aminotransferase (ALT), aspartate aminotransferase (AST)) and alkaline phosphatase (ALP) levels in WT and Mdr2-KO mice treated with vehicle or with CM414. (d) representative images of Sirius Red staining for collagen and immunostaining for $\alpha$-SMA, CD34, and CK19 in liver sections from WT and Mdr2-KO mice treated with vehicle or with CM414. Graphs on the right show the corresponding quantification of positively stained areas. ${ }^{*} p<0.05 .{ }^{* *} p<0.01 .{ }^{* * *} p<0.001$. 
Consistent with these histological observations, qPCR analyses of liver gene expression showed marked up-regulation of several genes associated with liver fibrogenesis, including collagen I $\alpha 1$ (ColI $\alpha 1)$, the interstitial collagenase matrix metalloproteinase 13 (Mmp13) and its inhibitor Timp1, lysyl oxidase ( $L o x$ ) and transforming growth factor $\beta 2$ (Tgf $\beta 2$ ), a TGF $\beta$ isoform strongly involved in biliary damage-related CLD [68] (Figure 4a). CM414 treated animals showed significantly reduced expression of all these genes, as that of Krt19, which encodes Ck19 and Tnc, which encodes tenascin C, a TGF $\beta$-inducible extracellular protein expressed in liver fibrogenic cells that participates in inflammation, fibrogenesis, and carcinogenesis [69] (Figure 4a). Consistent with previous reports [65], we also observed enhanced hepatocellular proliferation in $\mathrm{Mdr2-KO}$ mice, as evidenced by increased hepatocyte and cholangiocyte staining with the proliferation marker Ki67, a response that was also reduced by CM414 treatment (Figure 4b).

Inflammation is a potent driver of liver fibrosis [14], and an inflammatory response is also observed in the liver of Mdr2-KO mice, contributing to liver injury and ECM deposition [63,70]. Therefore, we investigated the degree of hepatic inflammatory infiltration by staining for the leukocyte marker CD45. We found that CM414 treatment significantly reduced the amount of CD45 positive cells (Figure 4c), and this response was accompanied by a downregulation in the expression of

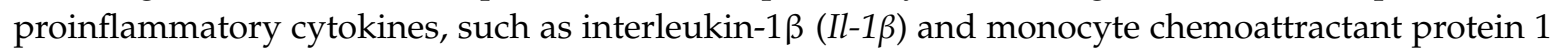
$(M c p-1)$, as well as the inducible NO synthase (iNos). Furthermore, the levels of the anti-inflammatory cytokine Il10, which are significantly reduced in Mdr2-KO compared with WT animals, were notably induced upon CM414 treatment (Figure 4d). Consistent with the inhibitory activity of CM414 towards PDE5, its administration to Mdr2-KO mice restored the hepatic contents of cGMP to levels similar to those found in WT animals (Figure 4e). All these results suggest that the simultaneous inhibition of Class I HDAC, HDAC6, and PDE5 activities results in a significant reduction in liver injury, fibrosis, and inflammation in $\mathrm{Mdr2}-\mathrm{KO}$ mice.

\subsection{Mechanisms of CM414 Anti-Fibrogenic and Anti-Inflammatory Effects}

To gain insight into the potential mechanisms of action of CM414 we used two different human cell lines, LX2 and H69, representative of liver ECM producing cells [71] and cholangiocytes [72], respectively. Similar to a previous report in neuroblastoma cells [56,57], in both LX2 and H69 cells, CM414 treatment resulted in a significant increase in total histone $\mathrm{H} 3$ lysine acetylation as well as histone H3 lysine 14 acetylation (H3K14Ac) levels (Figure 5a and Figure S1). Moreover, a significant increase was also observed in the levels of acetylated- $\alpha$-tubulin, the best-characterized HDAC6 substrate [33], was also observed (Figure 5b and Figure S1). To test the PDE5 inhibitory capacity of CM414 we evaluated the phosphorylation levels of vasodilator-stimulated phosphoprotein (VASP). Upon PDE5 inhibition, intracellular cGMP levels increase, leading to the activation of PKG, a crucial downstream mediator of the cGMP-mediated signaling pathways [73,74]. VASP is a prime substrate of PKGs, and phosphorylation of VASP at Ser239 (p-VASP) is commonly used to asses PKG activity [75]. Consistently, LX2 and H69 cells treated with CM414 presented higher levels of p-VASP compared with control cells (Figure $5 \mathrm{c}$ and Figure S1). All these data support the on-target activity of CM414, in LX2 and H69 cells, i.e., inhibition of Class I HDAC, HDAC6, and PDE5.

To further elucidate the anti-fibrogenic mechanisms of CM414, LX2 cells were incubated with the key fibrogenic cytokine TGF $\beta 1$ in the presence or the absence of this compound. Consistent with our in vivo findings, we observed a marked impairment of TGF $\beta 1$ effects on the expression of fibrogenic genes, including $\alpha-S M A, C O L I \alpha 1, P D G F R \beta$, and TGF $\beta 2$ (Figure 6a). On the contrary, the inhibitory effects of TGF $\beta 1$ on the expression of glial fibrillary acidic protein (GFAP), a marker or quiescent ECM producing cells, were blunted by CM414 (Figure 6a). Interestingly, when we analyzed in detail different components of the sGC-cGMP-PKG axis, we found that the expression of sGC was potently upregulated even in the absence of TGF $\beta 1$ stimulation (Figure $6 b, c$ and Figure S1). This finding suggests that in addition to preventing cGMP degradation through PDE5 inhibition, CM414 could also increase cGMP synthesis. The mRNA and protein levels of PKG were reduced upon 
TGF $\beta 1$ stimulation, strongly indicating that activation of myofibroblasts suppresses its expression, as previously described [76]. Concomitant treatment with CM414 and TGF $\beta 1$ resulted in the restoration of PKG levels (Figure 6b,c and Figure S1), and the levels of pVASP were also partially restored (Figure 6c and Figure S1). HDAC-mediated gene repression is also a critical event that precedes TGF $\beta 1$-induced pro-fibrotic gene expression. Transcriptional analyses revealed that TGF $\beta 1$ requires HDAC function to promote the repression of a broad complement of anti-fibrogenic genes [77]. We observed that specific anti-fibrogenic genes such as the orphan nuclear receptor 4 A1 (NR4A1) [78] or the metabolic regulator peroxisome proliferator activated receptor gamma co-activator-1 $\alpha(P G C-1 \alpha)$, recently identified as a key guardian of fibroblasts quiescence [79], were potently reactivated upon CM414 treatment (Figure 6d). Interestingly CM414 did not seem to modulate the canonical TGF $\beta 1$ signaling pathway in LX2, as indicated by the unaltered phosphorylation of SMAD3 (Figure 6e). However, CM414 treatment resulted in a significant decrease in phosphorylated AKT (pAKT) levels, both in control cells and also after TGF $\beta 1$ stimulation (Figure 6e). The inhibition of this signaling pathway is consistent with the mechanism of action of other cGMP modulators endowed with anti-fibrogenic properties $[53,54,80]$. Nevertheless, to better understand the mechanisms underlying the inhibitory effect of CM414 on TGF $\beta 1-A K T$ signaling we examined the expression of phosphatase and tensin homolog deleted on chromosome 10 (PTEN). PTEN is a negative regulator of the AKT pathway that is downregulated by epigenetic mechanisms in activated HSC, contributing to their activation [81]. We observed that CM414 treatment upregulated PTEN expression in LX2 cells (Figure S2a). Interestingly, CM414 also antagonized the upregulation of phosphatidylinositol-3 kinase (PI3K) catalytic subunit mediated by TGF $\beta 1$ (Figure S2b), a response that has been linked to the activation of lung fibroblasts and the development of pulmonary fibrosis [82,83].

Interestingly, we also found that CM414 significantly increased the expression of well-known endogenous antagonists of the WNT pathway [84], such as DKK1 and DKK2, members of the Dikkopf family (Figure 6f). These observations may be of mechanistic relevance, as it has been recently established that WNT signaling cooperates with TGF $\beta$-triggered pathways during fibrogenic activation of skin and lung fibroblasts [85]. Therefore, we first validated the crosstalk between TGF $\beta 1$ and WNT signaling in HSC activation. Here we show that when DKK1 expression was knocked-down in LX2 cells the effects of TGF $\beta 1$ on the expression of genes relevant to their fibrogenic activation, such as PDGFR $\beta$, WNT-5A, $c-M Y C$, and TGF $\beta 1$ itself, were markedly exacerbated (Figure S3). We confirmed that TGF $\beta 1$ reduced the expression levels of $D K K 1$ and $D K K 2$, while CM414 treatment inhibited this response (Figure $6 \mathrm{f}$ and Figure S4). We evaluated the expression of $c-M Y C$, a known target gene of WNT signaling, observing a significant increase upon TGF $\beta 1$ stimulation, and how this response was abated by CM414 (Figure 6f). Consistent with these observations, we found that the cellular levels of active $\beta$-catenin were downregulated upon CM414 treatment both in baseline conditions and after TGF $\beta 1$ stimulation (Figure $6 \mathrm{~g}$ and Figure S1).Interestingly, we also observed that CM414 inhibited the induction of WNT-5A expression elicited by TGF $\beta 1$ treatment (Figure 6h). WNT-5A is a WNT family member that activates the non-canonical WNT pathways, and importantly it plays a relevant role in TGF $\beta 1$ mediated HSC activation and liver fibrosis [86,87]. Upon activation, hepatic stellate cells are also able to trigger an inflammatory response [16]. Therefore, we evaluated the expression levels of the critical cytokine monocyte chemoattractant protein 1 (MCP1). TGF $\beta 1$ stimulation increased MCP1 expression in LX2 cells, and CM414 treatment also blunted this response (Figure 6i). 

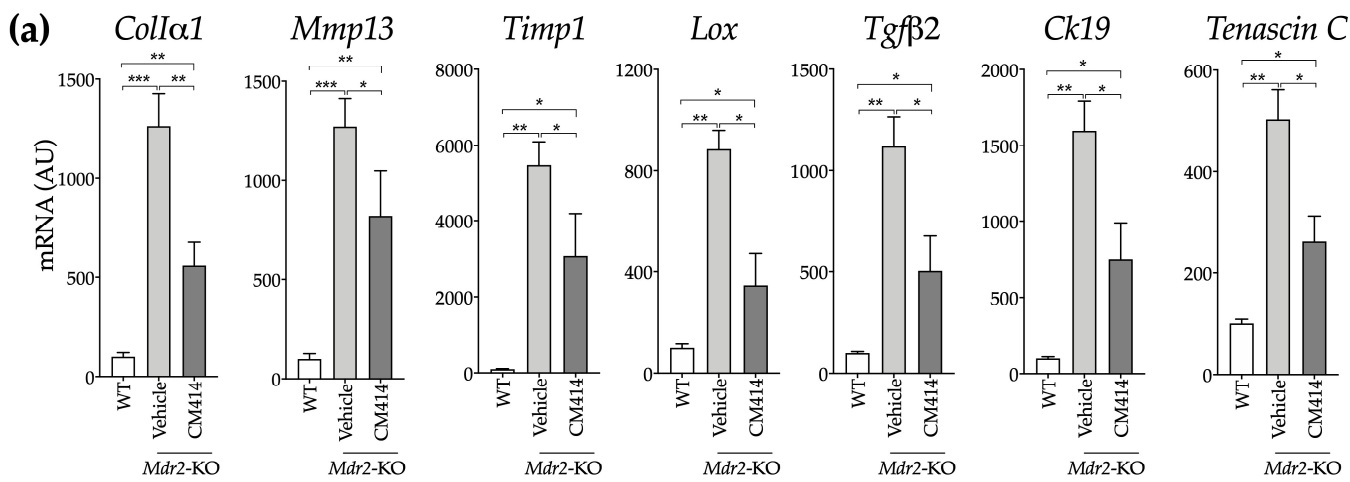

(b)
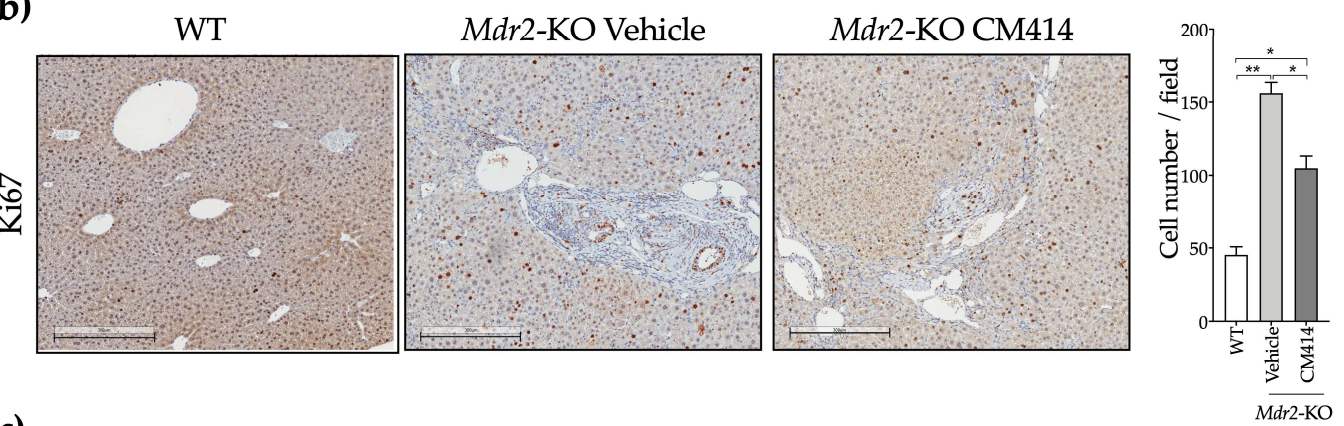

(c)

WT

Mdr2-KO Vehicle
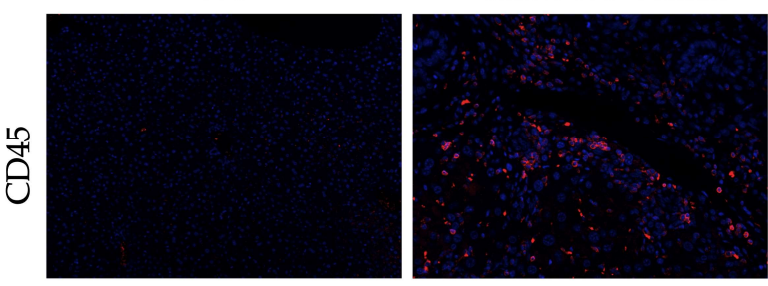

Mdr2-KO CM414
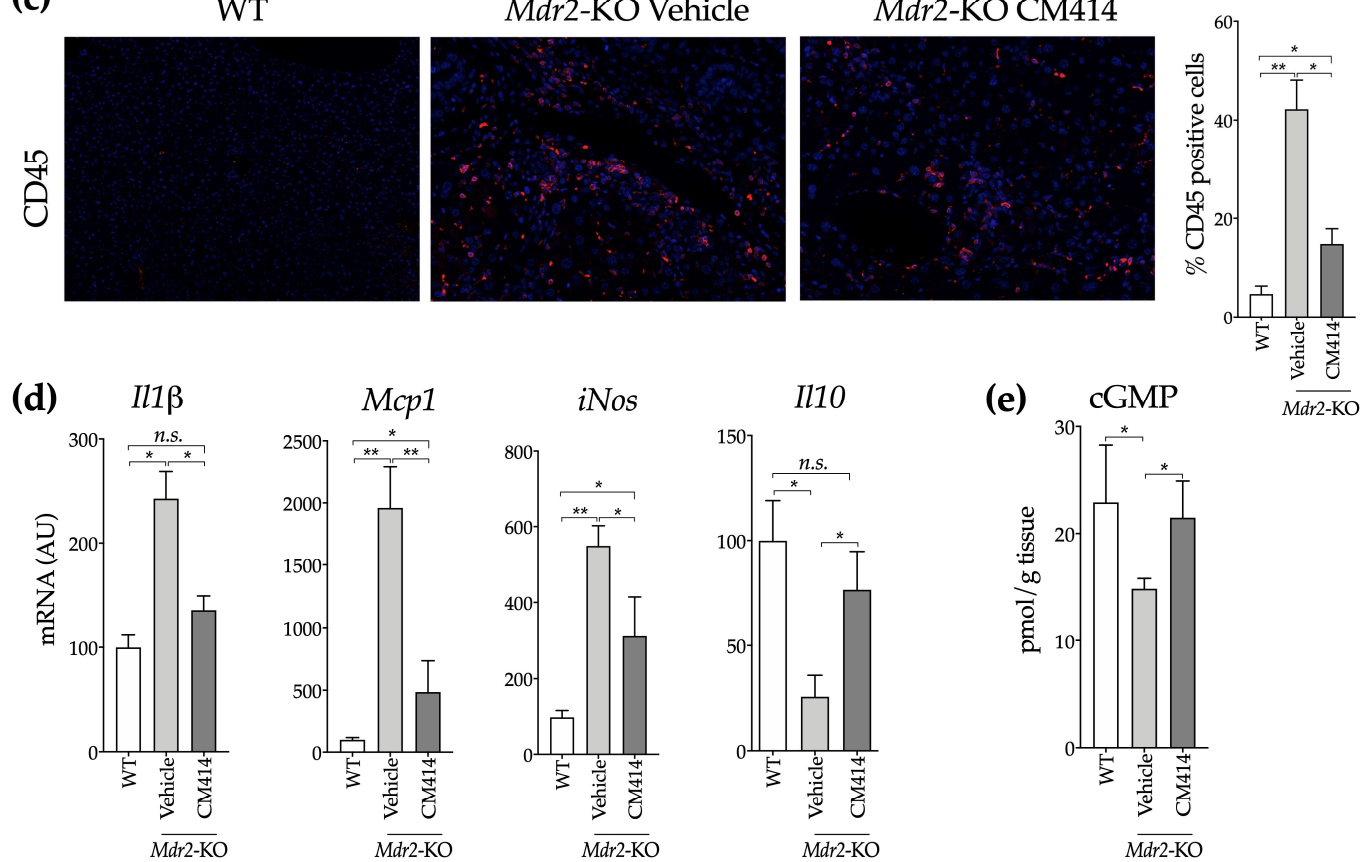

(e) cGMP

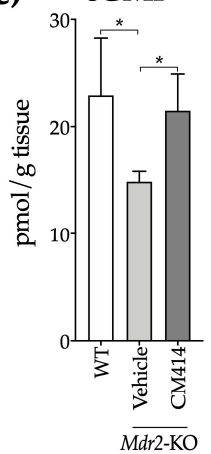

Figure 4. Evaluation of inflammation, fibrosis, and cell proliferation-related markers in the liver of WT, vehicle-treated Mdr2-KO, and CM414-treated Mdr2-KO mice. (a) qPCR analyses of the hepatic expression of fibrogenic activation-related genes. (b) representative immunohistochemical staining of Ki67 in liver sections. Graph on the right shows the quantification of Ki67 positive cells. (c) representative immunofluorescent staining of CD45 in liver sections. Graph on the right shows the quantification of CD45 positive cells. (d) qPCR analyses of the hepatic expression of inflammation-related genes. (e) analysis of cyclic guanosine monophosphate (cGMP) levels in mouse liver tissues. ${ }^{*} p<0.05$. ${ }^{* *} p<0.01 .{ }^{* * *} p<0.001$ 
(a)

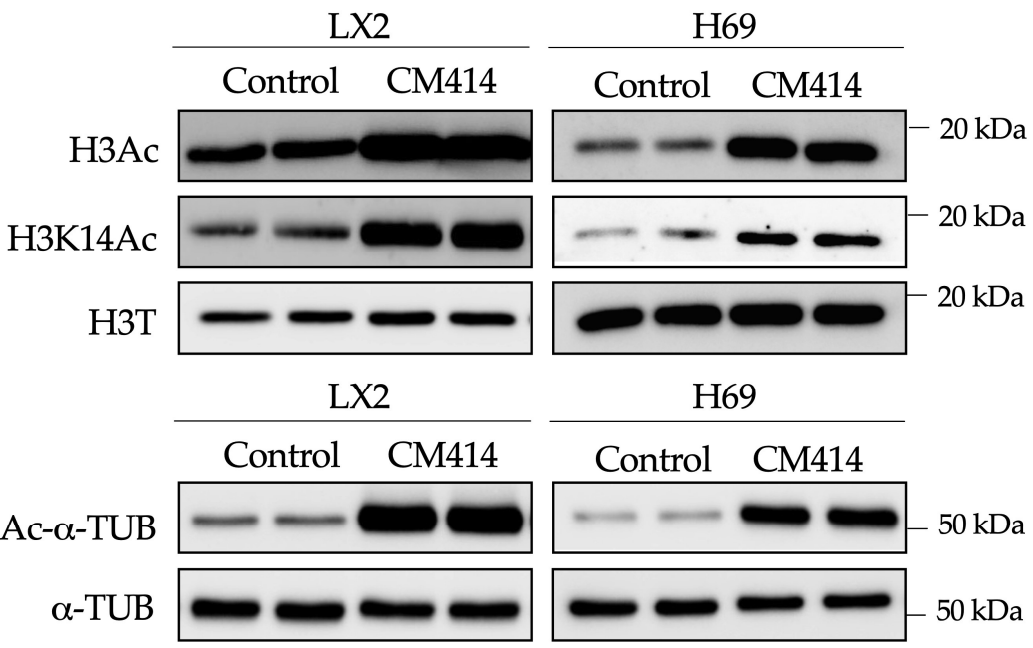

(c)

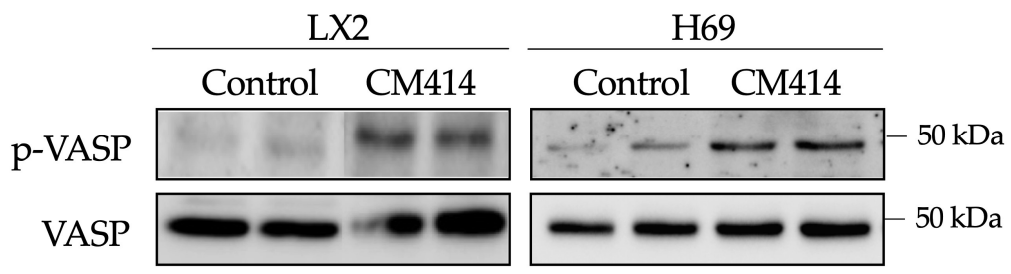

Figure 5. Evaluation of the on-target effects of CM414 in LX2 and H69 cells. (a) immunoblot analyses of total histone 3 acetylation (H3Ac), histone 3 acetylation at lys 14 (H3K14Ac) and total histone 3 (H3T) protein levels in LX2 (left panel) and H69 (right panel) cells treated for $1 \mathrm{~h}$ with CM414 (5 $\mu \mathrm{M})$. (b) immunoblot analyses of acetylated- $\alpha$-tubulin (Ac- $\alpha$-TUB) and $\alpha$-tubulin ( $\alpha$-TUB) protein levels in LX2 (left panel) and H69 (right panel) cells treated for $24 \mathrm{~h}$ with CM414 $(5 \mu \mathrm{M})$. (c) immunoblot analyses of phospho-vasodilator-stimulated phosphoprotein (VASP) and VASP protein levels in LX2 (left panel) and H69 (right panel) cells treated for $24 \mathrm{~h}$ with CM414 $(5 \mu \mathrm{M})$. Representative blots of three experiments performed in duplicate are shown.

In cholestatic liver injury and biliary fibrosis, diseased cholangiocytes become highly reactive, resulting in the release of several paracrine signaling molecules that subsequently activate portal fibroblasts and hepatic stellate cells in an epithelial/mesenchymal crosstalk [88,89]. To explore the potential effects of CM414 in this specific context, we used the human H69 cholangiocyte cell line. As previously described [90], H69 cells treated with TGF $\beta 1$ showed increased expression of the mesenchymal marker $\alpha$-SMA along with a marked increase in collagen production. These effects were, significantly, blocked by CM414 treatment (Figure 7a,b and Figure S1). Consistent observations were made in primary mouse cholangiocytes, in which CM414 also inhibited the expression of $\alpha$-Sma, ColI $\alpha 1, P d g f r \beta$, Tenascin C, and Tnf $\alpha$ elicited by TGF $\beta 1$ (Figure S5). Similar to what occurred in LX2 cells, CM414 potently induced the expression of know antagonists of the TGF $\beta$ pathway, such as the functional inhibitor of the TGF $\beta 1$ receptor, activin membrane-bound inhibitor (BAMBI) and PGC-1 $\alpha$ (Figure 7c). Moreover, the downregulation of these two genes in response to TGF $\beta 1$ treatment was blunted by CM414 (Figure 7c). Interestingly, in contrast to LX2 cells, in H69 cells, CM414 attenuated SMAD3 phosphorylation in response to TGF 31 (Figure 7d and Figure S1). 

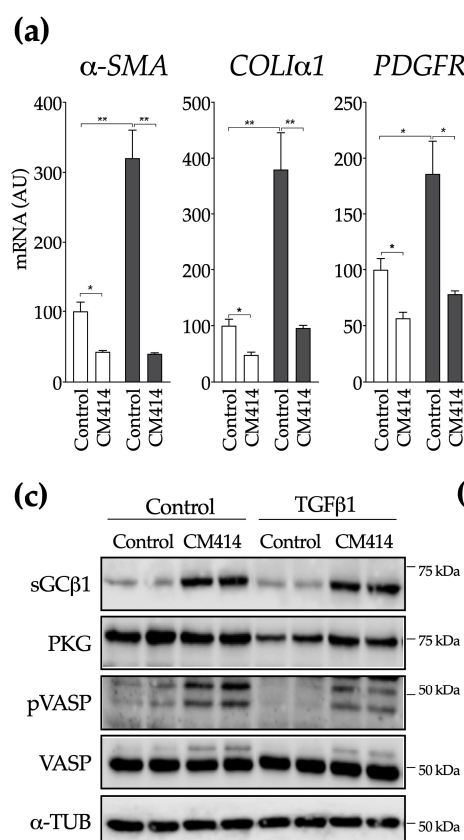

(d)
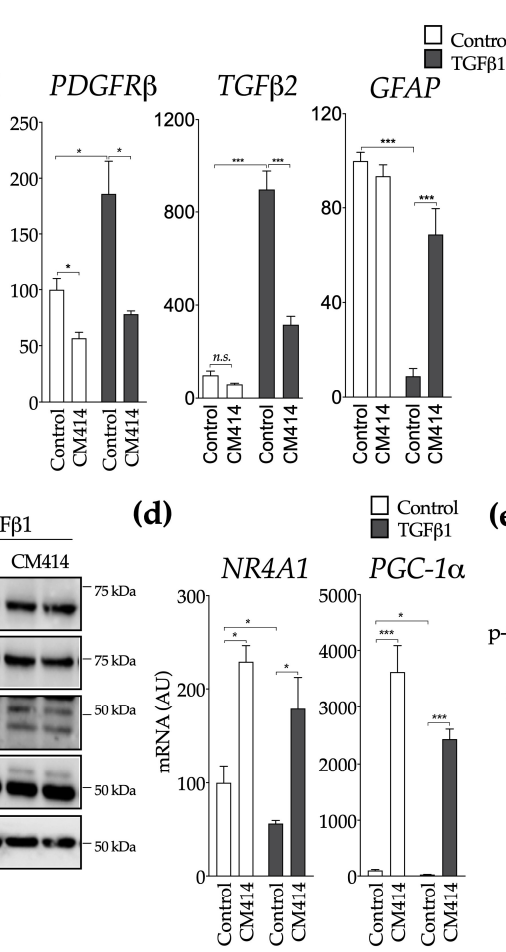

(b)
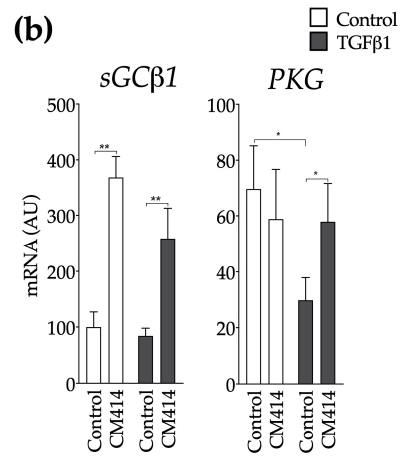

(e)
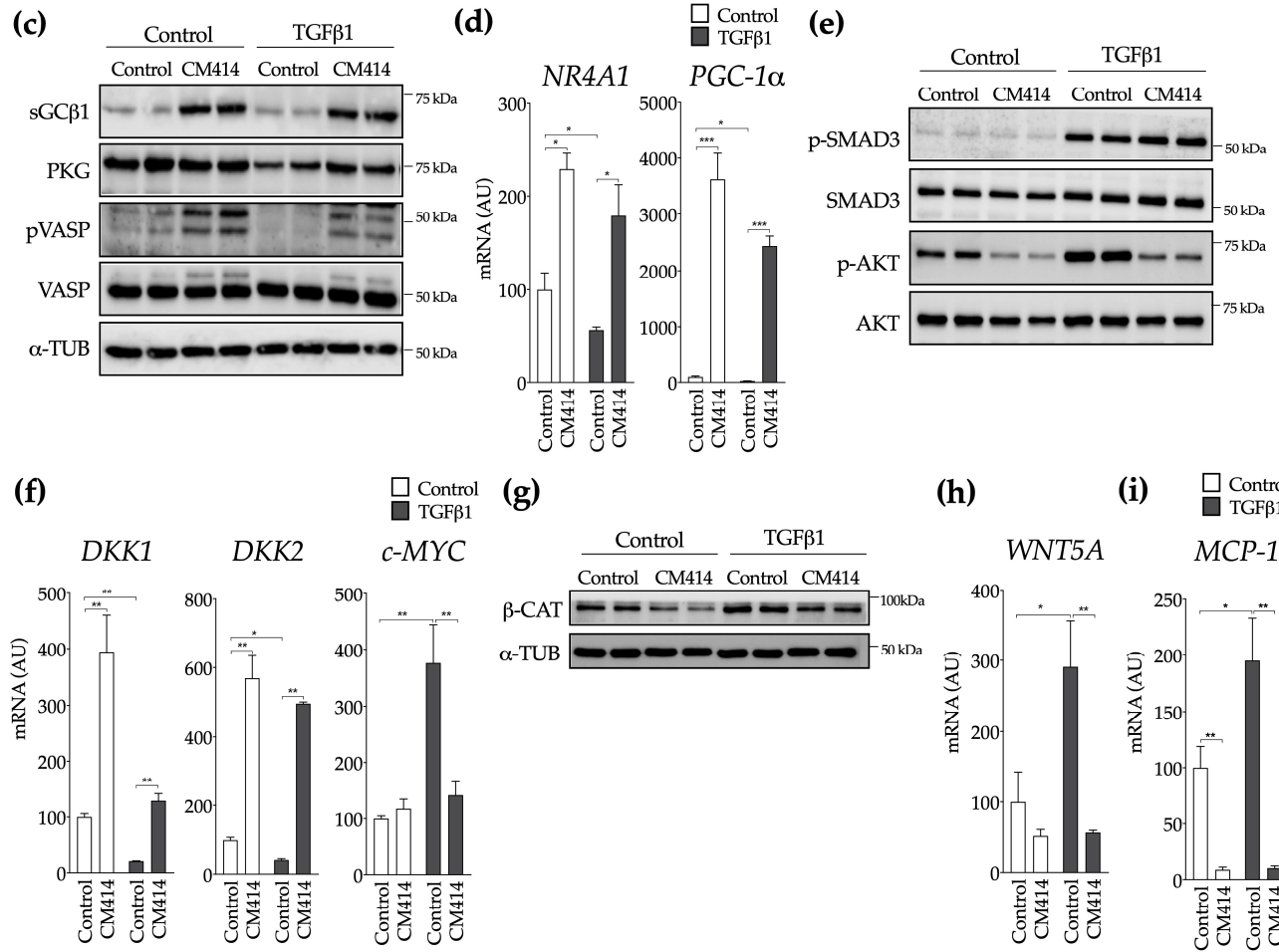

(g)

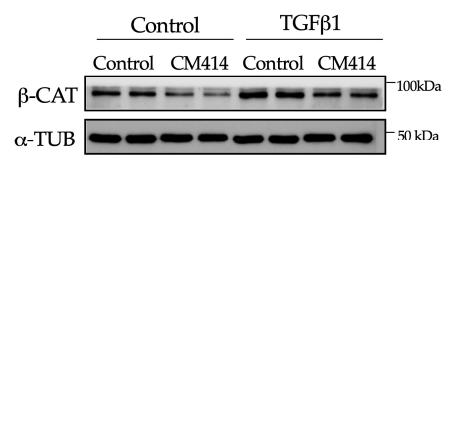

(h)

(i) $\square$ Control

WNT5A MCP-1
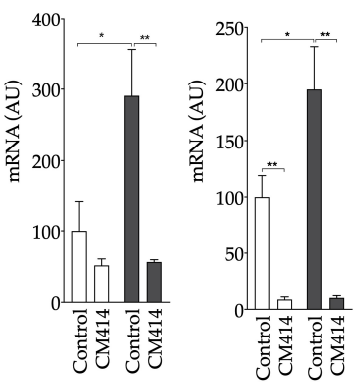

Figure 6. Effect of CM414 on transforming growth factor $\beta$ (TGF $\beta) 1$-mediated activation of LX2 cells. In all experiments LX2 cells were treated with CM414 $(5 \mu \mathrm{M})$ for $1 \mathrm{~h}$ and then stimulated with TGF $\beta 1(5 \mathrm{ng} / \mathrm{mL})$ for another $24 \mathrm{~h}$. (a) qPCR analysis of the expression of genes involved in fibrogenic activation. (b) qPCR analysis of the expression of sGC $\beta 1$ and protein kinase $\mathrm{G}$ (PKG). (c) immunoblot analysis of sGC $\beta 1$, PKG, phospho-VASP, VASP, and $\alpha$-TUB protein levels in LX2 cells treated as indicated. (d) qPCR analysis of the expression of nuclear receptor 4 A1 (NR4A1) and proliferator activated receptor gamma co-activator- $1 \alpha$ (PGC-1 $\alpha$ ) in LX2 cells treated as indicated. (e) immunoblot analyses of phospho-SMAD3, SMAD3, phospho-AKT and AKT protein levels in LX2 cells treated as indicated. (f) qPCR analyses of DKK1, DKK2, and c-MYC expression in LX2 cells treated as indicated. (g) immunoblot analyses of activated $\beta$-catenin ( $\beta$-CAT) and $\alpha$-TUB protein levels in LX2 cells treated as indicated. (h) qPCR analyses of WNT-5A expression in LX2 cells treated as indicated. (i) qPCR analysis of monocyte chemoattractant protein 1 (MCP1) mRNA expression in LX2 cells treated as indicated. Representative blots of three experiments performed in duplicate are shown. ${ }^{*} p<0.05$. ${ }^{* *} p<0.01{ }^{* * *} p<0.001$. 
(a)

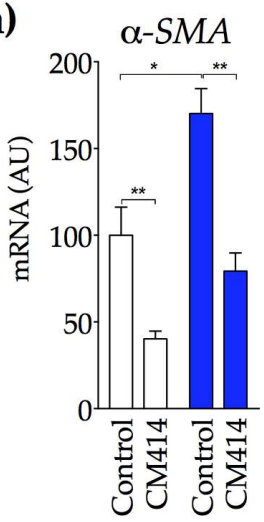

(c)

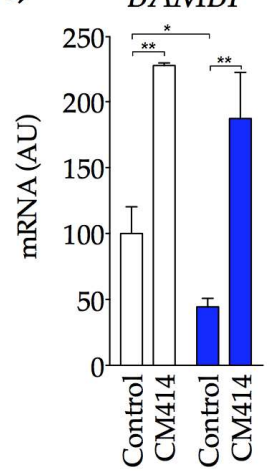

COLIa1

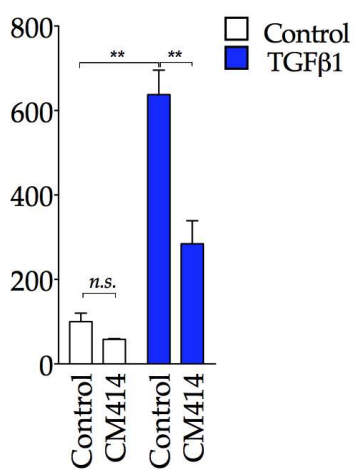

(b)
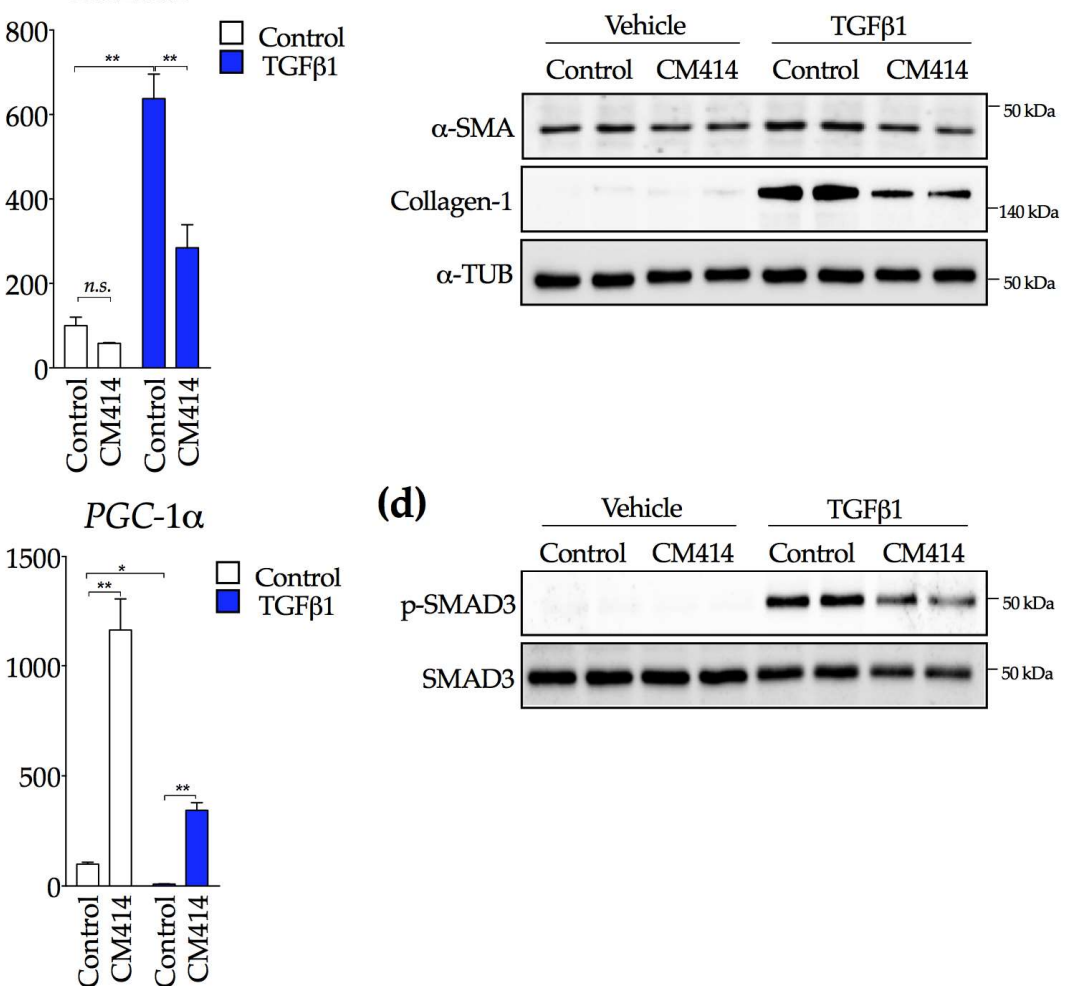

(e)

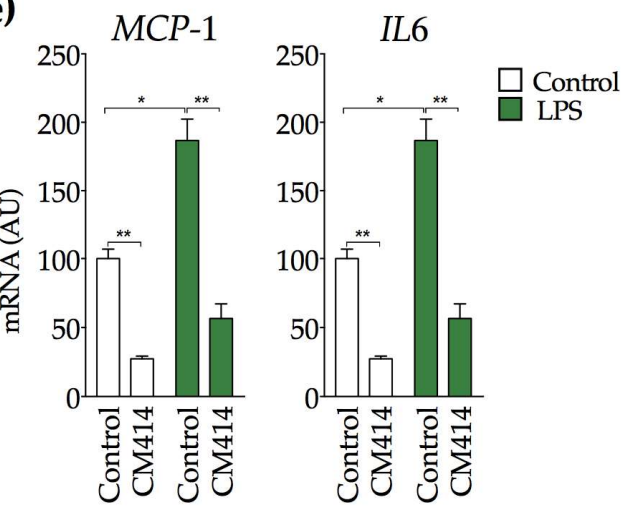

(d)

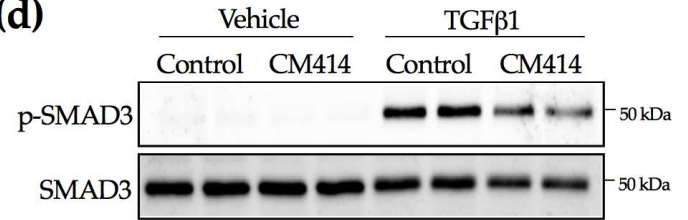

(f)

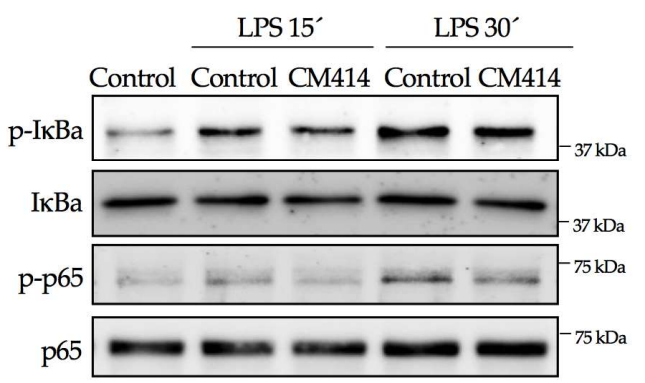

Figure 7. Effect of CM414 on TGF $\beta 1$ and lipopolysaccharide (LPS)-mediated activation of cholangiocytes. (a) qPCR analysis of $a-S M A$ and collagen I $\alpha 1$ (COLI $\alpha 1$ ) expression in $\mathrm{H} 69$ cells treated with CM414 $(5 \mu \mathrm{M})$ for $24 \mathrm{~h}$ and then stimulated with TGF $\beta 1(5 \mathrm{ng} / \mathrm{mL})$ for another $24 \mathrm{~h}$. (b) immunoblot analyses of $\alpha$-SMA, collagen- 1 and $\alpha$-tubulin protein levels in H69 cells treated as indicated above. (c) qPCR analyses of activin membrane-bound inhibitor (BAMBI) and PGC-1 $\alpha$ expression in $\mathrm{H} 69$ cells treated as indicated above. (d) immunoblot analyses of phospho-SMAD3 and SMAD3 protein levels in H69 cells treated as indicated above. (e) qPCR analysis of MCP1 and IL6 mRNA expression in H69 cells treated with CM414 $(5 \mu \mathrm{M})$ for $24 \mathrm{~h}$ and then stimulated with LPS $(1 \mu \mathrm{g} / \mathrm{mL})$ for another $24 \mathrm{~h}$. (f) immunoblot analyses of phospho-IкBa, IкBa, phospho-p65 and p65 protein levels in H69 cells treated with CM414 $(5 \mu \mathrm{M})$ for $24 \mathrm{~h}$ and then stimulated with LPS $(1 \mu \mathrm{g} / \mathrm{mL}$ for $15 \mathrm{~min}$ and $30 \mathrm{~min}$. Representative blots of three experiments performed in duplicate are shown. ${ }^{*} p<0.05 .{ }^{* *} p<0.01$.

To further evaluate the anti-inflammatory properties of CM414, H69 cells were exposed to bacterial lipopolysaccharide (LPS) in order to trigger an inflammatory response. LPS significantly increased MCP1 and IL6 mRNA levels, whereas CM414 treatment completely prevented these responses. It is worth noting that CM414 markedly inhibited the expression of these genes even in the absence of LPS (Figure 7e). The NF-kb signaling system is a crucial intracellular mediator of inflammatory responses 
elicited by different stimuli, including LPS [91]. Therefore, we determined the effects of CM414 on the activation of this pathway. H69 cells were stimulated with LPS in the absence and the presence of CM414, and we examined the levels of IkBa and p65 phosphorylation (p-IkBa and p-p65) at different time points. As shown in Figure $7 \mathrm{f}$ (and Figure S1), CM414 attenuated the stimulatory effects of LPS on these two essential components of the NF-kb pathway. Moreover, the inhibitory effects of CM414 were also observed in the mouse macrophage cell line RAW264.7. CM414 attenuated the activation of the NF-kb pathway (p65 phosphorylation) by LPS and consistently reduced Tnf $\alpha, I l 1 \beta$, and $i$ Nos expression (Figure S6). Together, these observations demonstrate that CM414 not only possesses potent anti-fibrogenic properties but also presents a significant anti-inflammatory activity through inhibition of the NF-kb pathway.

\section{Discussion}

Chronic hepatic injury and inflammation, regardless of its etiology, results in an unresolved wound healing process, which paves the way for liver cancer development [92,93]. Pharmacological interference with this dysregulated wound healing response may restore liver parenchymal architecture and function and prevent tumor development [94]. Here we have identified CM414, a first-in-class multi-targeted small molecule inhibitor as a potential tool to explore new anti-fibrogenic therapeutic avenues. The complex and multifactorial nature of liver fibrogenesis suggests that the simultaneous interference with different targets with a single molecule would likely be more effective. Moreover, considering that a deteriorated liver function is a hallmark of CLD, multi-targeted, but still, selective inhibitors may be less toxic than drug combinations, as pharmacological interactions would be avoided.

To test the anti-fibrogenic effects of CM414, we took advantage of Mdr2-KO mice, which as mentioned above, is a clinically relevant model of spontaneous CLD, fibrosis, and HCC/CCA development. First, we examined the expression of CM414 molecular targets in Mdr2-KO mice once inflammation and fibrosis are well established in this model [62]. Compared to WT mice, our IHC analyses clearly showed increased levels of HDAC1, HDAC6, and PDE5 in different liver cell types, including hepatocytes, ECM producing cells, and cholangiocytes. Next, we tested the effects of sustained CM414 administration on various parameters related to CLD progression. CM414 was well tolerated, which is an important issue when testing drugs in animals with impaired liver function. Moreover, CM414 dosing led to a decrease in liver-to-body weight ratio and improved serum markers of hepatic injury. This was accompanied by reduced hepatic fibrosis, reduced abundance of fibrogenic cells, and an attenuated ductular reaction. Accordingly, expression levels of genes implicated in myofibroblast activation, ECM accumulation, and overall tissue remodeling activity were lower in CM414 treated Mdr2-KO mice. Moreover, the levels of TGF $\beta 2$, previously shown to be specifically expressed in epithelial cells of proliferating bile ducts and fibrotic liver, contributing to ductular reaction, biliary damage, and fibrosis [68], were also reduced. Interestingly CM414 also lowered the expression of Tenascin C in Mdr2-KO treated mice. This ECM glycoprotein is minimally detected in healthy tissue but is transiently expressed during tissue injury, playing a role in fibrogenesis and also in tumorigenesis [69]. Tenascin C levels are significantly high in patients with chronic hepatitis C, liver cirrhosis, and HCC $[95,96]$. Its attenuation by CM414 could therefore identify a chemopreventive activity of CM414 towards HCC development. In line with this assumption, hepatocellular proliferation, which has been associated with enhanced risk of HCC development in chronic liver injury [97], was also diminished by CM414 treatment. The persistent inflammation associated with the progression of liver disease in $\mathrm{Mdr2-KO}$ mice was also attenuated, as indicated by decreased numbers of infiltrating leukocytes (CD45 positive cells) and reduced expression of inflammation-related genes. Moreover, CM414 restored the expression of the anti-inflammatory cytokine Il10, which is reduced in the liver of Mdr2-KO mice compared with WT animals. Taken together, these observations suggest that the concomitant inhibition of HDAC Class I, HDAC6, and PDE5 present not only anti-fibrogenic effects but also significant anti-inflammatory properties. Interestingly, we also observed that CM414 administration to Mdr2-KO mice restored the intrahepatic levels of cGMP to values similar to those 
found in WT animals. Enhanced intrahepatic cGMP availability has been recently observed in cirrhotic bile-duct ligated rats treated with the PDE5 inhibitor tadalafil. Tadalafil treatment improved liver fibrosis and inflammation, and also decreased portal pressure [98], suggesting that CM414 could also be useful for the management of portal hypertension [99].

From a mechanistic point of view, it is worth noting that the three different enzymatic inhibitory activities harbored by CM414 have been separately described to interfere with TGF $\beta$ signaling at multiple levels. Indeed, other Class I HDACs [27], HDAC6 [39], or PDE5 [80] inhibitors have been reported to hamper the proliferation and decrease the differentiation of liver fibroblasts into ECM-producing cells. We observed a significant impairment of TGF $\beta 1$-induced effects on the expression of crucial fibrogenic genes in LX2 cells treated with CM414. This response was not apparently due to interference with TGF 31 -SMAD signaling, as p-SMAD3 levels remained unaltered in the presence of CM414. However, Akt activation, a "non-canonical" TGF $\beta$ signaling pathway, also involved in the survival, proliferation, and collagen production of HSCs [100-102], was markedly inhibited by CM414. Interestingly, interference with TGF $\beta$-mediated activation of Akt has also been observed in response to other histone deacetylase inhibitors, such as largazole [103], or upon PDE5 inhibition [80] in experimental models of liver fibrosis. The observed upregulation of PTEN, and the inhibition of TGF $\beta 1$-triggered PI3K gene expression, may also underlie the mechanisms through which CM414 interferes with TGF $\beta 1-A k t$ signaling and HSC fibrogenic activation [81-83].

Interestingly we detected a significant increase in the expression of sGC in LX2 cells treated with CM414, both in the absence and the presence of TGF $\beta 1$. This effect may be attributed to an epigenetic mechanism mediated by Class I HDACs. Indeed, it has been shown that Class I HDAC inhibitors increase the expression of $s G C$, and more specifically, that HDAC3 represses its expression [104]. The fact that CM414 is able to upregulate the enzyme accounting for the production of cGMP, together with its intrinsic PDE5 inhibitory activity, makes this molecule a potent activator of cGMP-mediated signaling. This facet of CM414 pharmacological activity may certainly underlie the anti-fibrogenic effects observed in this study. Indeed, sGC stimulators are being actively studied due to their promising anti-fibrogenic actions not only in liver fibrosis [53] but also in other related conditions, such kidney fibrosis [105] and systemic sclerosis [54]. In these studies, it was also demonstrated that PKG activity was essential for the antifibrotic effects of sGC stimulators [106]. The impairment of the sGC-cGMP-PKG pathway in fibrotic tissues is phenocopied by TGF $\beta 1$ stimulation of ECM producing cells. In our hands, TGF $\beta 1$ treatment of LX2 cells significantly decreased PKG expression, while CM414 treatment averted this response. Together, these findings indicate that CM414 can have a multifaceted positive effect on the sGC-cGMP-PKG pathway, counteracting the inhibitory influence of TGF $\beta 1$ and thus, opposing the fibrogenic activation of liver myofibroblasts. On the other hand, through the inhibition of Class I HDACs, CM414 can favor the transcription of potential inhibitors of myofibroblast activation and fibrosis. In this respect, we observed a marked increase in the expression of genes such as PGC-1 $\alpha, N R 4 A 1$, and BAMBI in LX2 or H69 cells upon CM414 treatment. Several studies have shown how TGF $\beta 1$ signaling leads to the repression of all these genes through epigenetic HDAC-dependent mechanisms $[77,78,107]$. Interestingly, we also observed that other negative regulators of pathways concomitantly triggered by TGF $\beta$, such as the WNT signaling pathway, were upregulated upon CM414 treatment. The WNT/ $\beta$ catenin pathway also plays a crucial role in the progression of fibrosis [108], engaging in a pro-fibrogenic crosstalk with TGF $\beta$ signaling [85]. CM414 treatment led to the upregulation of the WNT antagonists DKK1 and DKK2, which are capable of suppressing the nuclear translocation of $\beta$-catenin and the induction of its transcriptional targets [84]. Other epigenetic mechanisms have been reported to participate in the transcriptional regulation of WNT antagonists [109]. The results of the present study have shown that Class I HDACs can also play a role, and HDACs inhibition could constitute a novel approach to interfere with the TGF $\beta / W N T$ signaling network in the context of liver fibrogenesis. Moreover, we also found that CM414 can interfere with the crosstalk between TGF $\beta 1$ and non-canonical WNT signaling. We observed that 
CM414 abrogated the effects of TGF $\beta 1$ on the expression of WNT-5A, a prominent growth factor of the non-canonical WNT pathway involved in liver fibrosis and TGF 31 -mediated HSC activation [86,87].

The epithelial to mesenchymal transition (EMT) has been identified as another biological process contributing to the pathogenesis of liver fibrosis [110]. In experimental models, EMT can be counteracted by HDACis, such as Class I HDACi, promoting the restoration of adherent junctions between epithelial cells [111], and HDAC6 inhibitors, which increase acetylated $\alpha$-tubulin levels, resulting in microtubule stabilization [40,112]. In the Mdr2-KO model, EMT is particularly relevant, reproducing pathological features of human CLD [113]. Following liver injury and inflammation, cholangiocytes are activated and undergo trans-differentiation from epithelial to mesenchymal phenotype [110,114]. As mentioned above, CM414 treatment significantly attenuated the ductular reaction and the development of biliary fibrosis in $\mathrm{Mdr2-KO}$ mice. These responses may be due, in part, to a direct effect of CM414 on biliary epithelial cells. This contention is supported by our observations in $\mathrm{H} 69$ cells and primary mouse cholangiocytes. In these cells, TGF $\beta 1$ stimulation resulted in potent activation of a mesenchymal phenotype, including $\alpha$-SMA expression and COLI $\alpha 1$ protein production, and interestingly, CM414 blocked this EMT-related response.

Finally, our in vivo and in vitro observations revealed remarkable anti-inflammatory properties for CM414, including the attenuation of parenchymal infiltration of inflammatory cells. Mechanistically, this effect could also be attributable to the different pharmacological activities of CM414. Several studies have reported how Class I HDAC [115], HDAC6 [36,37], and PDE5 [45,46] inhibitors present anti-inflammatory properties, which can be mediated by modulation of the NF- $\mathrm{kB}$ signaling pathway, as we observed in $\mathrm{H} 69$ cells and RAW264.7 macrophages. These anti-inflammatory activities may also contribute to the hepatoprotective effects of CM414 observed in Mdr2-KO mice, as inflammation is a key driver of liver damage in this model [63].

\section{Materials and Methods}

\section{1. $C M 414$}

This molecule was designed using knowledge and structure-based approaches according to reported structure-activity relationships (SARs), available data regarding HDAC and PDE5 inhibition, and structural information, including the X-ray co-crystal structures for the HDAC2-vorinostat complex (PBD 4LXZ) and the PDE5-sildenafil complex (PDB 1TBF) (Chemical Computing Group, Molecular Operating Environment, MOE 2012.10 (2012), Montreal, Quebec, Canada; http://www.chemcomp.com/) [56]. Previous extensive multifactorial optimization of CM414 through medical chemistry, absorption, distribution, metabolism and excretion properties (ADME) studies, and cardiovascular safety and toxicity analyses highlighted this compound as an interesting pharmacological tool [58].

\subsection{Animal Studies}

Female Mdr2-KO- and Mdr2-WT mice (The Jackson Laboratory, BarHarbor, ME, USA) fed a standard laboratory diet were used in this study. Two littermates groups of 6-month-old Mdr2-KO mice were established. One group was treated daily with CM414 $(40 \mathrm{mg} / \mathrm{kg}$, i.p. $)(n=5)$ or vehicle $(10 \%$ DMSO, $10 \%$ Tween-20 in saline solution) $(n=5)$ for 4 weeks. The control group of Mdr2-WT mice $(n=8)$ received the same volume of vehicle. This dose of CM414 was selected from a previous study [56]. At the end of treatments serum was withdrawn and animals were euthanized. Livers were excised, weighted, and were either span frozen of fixed in formalin and paraffin-embedded. Serums levels of liver enzymes levels were analyzed in a Cobas analyzer (Roche, Mannheim, Germany) as previously described [20,116-118]. cGMP levels in mouse liver tissues were measured with the Cyclic GMP ELISA kit from Cayman Chemical (581021) as recommended by the supplier. The study was approved by the Ethics Committee for Animal Experimentation of the University of Navarra (Protocol number 086-19). 


\subsection{Immunohistochemistry and Tissue Staining}

Immunohistochemical detection of HDAC1 (antibody sc-81598, Santa Cruz Biotech, CA, USA), HDAC2 (sc-9959, Santa Cruz Biotech), HDAC6 (SAB500012, Sigma Aldrich, St. Louis, MO, USA), PDE5 (ab14672, Abcam, Cambridge, UK), $\alpha$-SMA (A2547, Sigma Aldrich), CK-19 (ab9221, Abcam), Ki67 (ab15580, Abcam), CD45 (clone 30-F11,103101, BioLegend, San Diego, CA, USA), and CD34 (ab81289, Abcam) was performed on $3 \mu \mathrm{m}$ thick formalin-fixed paraffin embedded mouse tissue following standard protocols as we described before [20,119]. Paraffin was removed and the tissues rehydrated using a slide wash/incubation sequence with Histo-Clear II (National Diagnostics, Nottingham, UK), ethanol 10\%, 90\%, and 70\%, and $\mathrm{ddH}_{2} \mathrm{O}$. Antigen retrieval was performed with Tris-EDTA Buffer/Citrate Buffer (Dako, Glostrup, Denmark) and sections were incubated with primary antibodies diluted in blocking solution (1\% BSA in PBS) overnight at $4{ }^{\circ} \mathrm{C}$. After washing, sections were incubated with secondary antibodies diluted in 1\% BSA in PBS for another $1 \mathrm{~h}$ at room temperature and then washed and visualized with 3,3'-diaminobenzidine tetrahydrochloride (DAB) (Dako) counterstained with hematoxylin. The primary antibody for HDAC1 detection was diluted 1:100, HDAC2 1:100, HDAC3 1:100, HDAC6 1:100, PDE5 1:50, $\alpha$-SMA (1:100), CK-19 (1:200), Ki67 (1:500), and CD45 (1:100), and the secondary antibody was anti-rabbit Envision + System-HRP (Dako) for all the antibodies used except Goat anti-rat Alexa Fluor 555 (A21434, Invitrogen, Carlsbad, CA, USA) for CD45. For microscopy and image analyses tissues were viewed under a Zeiss LSM 800 confocal microscope (Zeiss, Oberkchen, Germany). Images were processed and analyzed using ImageJ software [120].

\subsection{Cell Culture and Treatments}

The human HSC line LX2 [71] obtained from Millipore-Merck (Darmstadt, Germany), was cultured in Dulbecco's Modified Eagle Medium (DMEM) supplemented with 2\% FBS and 100 U/mL penicillinstreptomycin. H69 cells, an SV40-transformed (i.e., immortalized) human cholangiocyte cell line [72], were grown in DMEM Nutrient Mixture F-12 (DMEM/F-12) + GlutaMax supplemented with 10\% FBS and $100 \mathrm{U} / \mathrm{mL}$ penicillin-streptomycin. RAW264.7 mouse macrophages were from the American Type Culture Collection (ATCC) and were cultured in DMEM supplemented with 10\% FBS and $100 \mathrm{U} / \mathrm{mL}$ penicillin-streptomycin. Mouse cholangiocytes were isolated from $M d r 2-W T$ male mice as we previously described [121] and cultured in thick collagen in fully supplemented DMEM/F-12 medium [122].

All cell cultures were maintained under standard conditions in a humidified incubator under $5 \% \mathrm{CO}_{2}$ in air at $37^{\circ} \mathrm{C}$. TGF $\beta 1$ and lipopolysaccharide stimulation of LX2 and H69 cells was performed at $5 \mathrm{ng} / \mathrm{mL}$ and $1 \mu \mathrm{g} / \mathrm{mL}$, respectively, while RAW264.7 cells were treated with 100 or $200 \mathrm{ng} / \mathrm{mL}$ LPS, as indicated. Recombinant human TGF $\beta 1$ was from R\&D Systems (Minneapolis, MN, USA) and Salmonella typhimurium LPS from Sigma-Aldrich (St. Louis, MO, USA). In vitro treatments were performed at indicated times and doses, and controls received the same concentrations of DMSO (always $<0.1 \%$ of final volume). For the knockdown of DKK1 expression in LX2 cells we used control siRNAs (siC) and DKK1-specific siRNAs (siDKK1) from Santa Cruz Biotechnology (sc-37082). Transfections were performed as described [20].

\subsection{Immunoblotting}

Cells and tissues were lysed in RIPA buffer. Histones were extracted as described below. Samples were subjected to western blot analysis as reported [20,117]. Primary antibodies were: $\alpha$-tubulin (T6074, Sigma-Aldrich), SMAD3 (C67H9, Cell Signaling, Danvers, MA, USA), pSMAD3 (C25A9, Cell Signaling), $\alpha$-SMA (F3777, Sigma-Aldrich), VASP (3112, Cell Signaling), pVASP (Ser239) (3114, Cell Signaling), GUCY1B3, sGC1ß (ab15484) (ab154841, Abcam), PKG-1 (3248, Cell Signaling), histone-3 (05-928, Millipore), Acetyl-Histone H3 (Lys14) (06-911, Millipore), pAKT (Ser473) (9271, Cell Signaling), AKT (9272, Cell Signaling), active $\beta$-catenin (05-665, Millipore), collagen-I (ab138492, Abcam, USA), and DKK1 (AF1096, R\&D Systems). For quantification of immunoblot signals we used the Image Lab Software from Bio-Rad Laboratories. 


\subsection{RNA Isolation and Quantitative Real-Time RT-PCR}

RNA was extracted from liver tissues and cells using the automated Maxwell system from Promega (Madison, WI, USA) according to the manufacturer's instructions. For retro-transcription RNA samples were exposed for $1 \mathrm{~min}$ at $90{ }^{\circ} \mathrm{C}$ for denaturalization followed by $1 \mathrm{~h}$ at $37^{\circ} \mathrm{C}$ using a mix containing: $50 \mathrm{mM}$ Tris- $\mathrm{HCl} \mathrm{pH} 8.3,75 \mathrm{mM} \mathrm{KCl}$ and $3 \mathrm{mM} \mathrm{MgCl}, 10 \mathrm{ng} / \mu \mathrm{L}$ of random primers, $0.5 \mathrm{mM}$ of each deoxyribonucleic triphosphate (dNTP), $5 \mathrm{mM}$ of dithiothreitol (DTT), $1.2 \mathrm{U} / \mu \mathrm{L}$ RNase inhibitors (RNase out) and $6 \mathrm{U} / \mu \mathrm{L}$ of M-MLV inverse transcriptase enzyme. All reagents from Invitrogen (Carlsbad, CA, USA), except dNTPs that were from Roche Diagnostics (Mannheim, Germany). Resulting complementary DNA (cDNA) were used to measure differences among gene expression levels. With the resulting cDNAs qPCR reactions were performed in a Bio-Rad CFX96 Real-Time System thermal cycler using iQ SYBR Green Supermix reagent from Bio-Rad (Hercules, CA, USA) following manufacturer's instructions. Primers are listed in the Table A1. Relative quantification of mRNA was calculated with the $-\Delta \Delta C T$ method using the reference gene of constitutive expression H3F3A as we described [20].

\subsection{Histone Extraction}

Histones were isolated as previously described [123]. Briefly, cells were lysed in a buffer containing $10 \mathrm{mM}$ Tris- $\mathrm{HCl} \mathrm{pH} \mathrm{7.4,} 10 \mathrm{mM} \mathrm{NaCl}$, and $3 \mathrm{mM} \mathrm{MgCl}_{2}$. After centrifugation at $2500 \mathrm{rpm}$ for $10 \mathrm{~min}$ at $4{ }^{\circ} \mathrm{C}$ supernatants were removed, and pellets were lysed in the previous buffer but containing $0.5 \%$ NP40 on ice for $10 \mathrm{~min}$ with gentle stirring. Nuclei were pelleted by centrifugation at $2500 \mathrm{rpm}$ for $10 \mathrm{~min}$ at $4{ }^{\circ} \mathrm{C}$ and resuspended in $5 \mathrm{mM} \mathrm{MgCl}_{2}$ and $0.8 \mathrm{M} \mathrm{HCl}$. Nuclei were incubated in this buffer during $30 \mathrm{~min}$ at $4{ }^{\circ} \mathrm{C}$ to extract the histones. Samples were then centrifuged at $14,000 \mathrm{rpm}$ for $10 \mathrm{~min}$ at $4{ }^{\circ} \mathrm{C}$ to pellet debris and supernatants were transferred to a clean tube where TCA $50 \%$ was added to precipitate the histones. After washing the pellets with acetone they were air-dried and resuspended in $100 \mathrm{mM}$ Tris- $\mathrm{HCl} \mathrm{pH} 7.5,1 \mathrm{mM}$ EDTA and 1\% SDS. The histone concentration in the extract was measured using the BCA assay (Pierce Technologies, Rockford, IL, USA) according to manufacturer's specifications.

\subsection{Statistical Analyses}

Data are means \pm SEM. Data was compared using the Student $t$ test. A $p$ value of $<0.05$ was considered significant. Data analyses were performed using GraphPad Prism software version 7.0 (GraphPad Software Inc., San Diego, CA, USA).

\section{Conclusions}

Our study supports the notion that simultaneous targeting of different mechanisms involved in liver fibrosis and inflammation with a single molecule can be a new disease-modifying strategy. Here we illustrated this concept in a clinically relevant mouse model with established liver fibrosis using a novel class of multi-targeted molecular probes represented by CM414. Our findings show that combined inhibition of specific HDACs (Class I and HDAC6) and PDE5 results in potent anti-inflammatory and anti-fibrogenic effects in vivo in the absence of apparent toxicity (Figure 8). Mechanistically, our in vitro experiments indicate that inhibition of TGF $\beta$ expression and activity, restoration of the sGC-cGMP-PKG pathway, and attenuation of NF-kb inflammatory signaling may underly the beneficial effects of CM414. Therefore, the development of novel drugs based on compounds such as CM414 may open new avenues for the treatment of CLD and the prevention of malignant transformation of liver cells. 


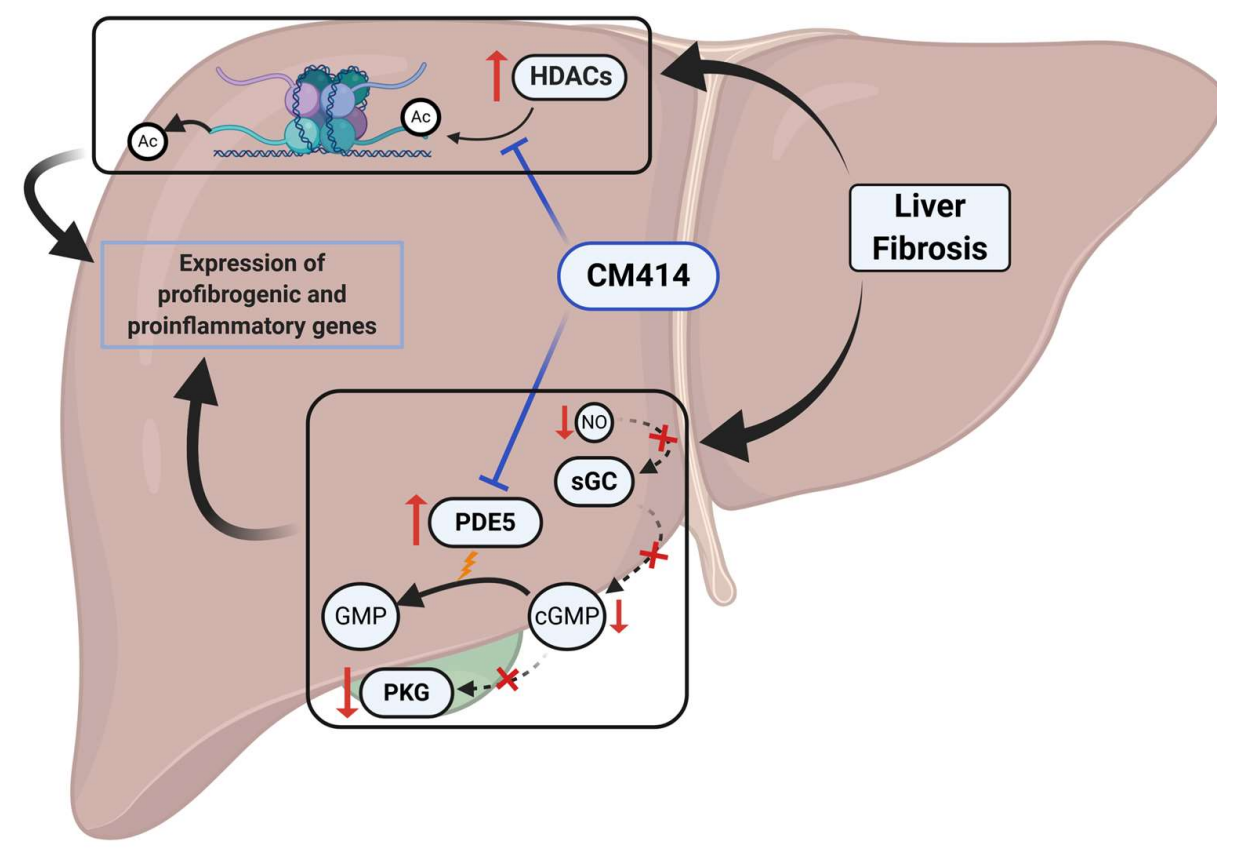

Figure 8. Proposed mechanisms of action of CM414 involved in the inhibition of liver fibrosis and inflammation.

Supplementary Materials: The following are available online at http://www.mdpi.com/2072-6694/12/12/3748/s1, Figure S1: Densitometric analyses of the immunoblots shown in Figures 5-7, Figure S2: (a) effect of CM414 treatment on the expression of PTEN in LX2 cells treated for $48 \mathrm{~h}$ with CM414 $(5 \mu \mathrm{M})$ analyzed by qPCR. (b) effect of TGF $31(5 \mathrm{ng} / \mathrm{mL})$ on the expression of PI3K catalytic subunit in LX2 cells. Treatments were performed for $24 \mathrm{~h}$ in the absence or presence of CM414 $(5 \mu \mathrm{M})$ as indicated, Figure S3: (a) qPCR analysis of DKK1 gene expression in LX2 cells transfected with control siRNA (siC) or DKK1-specific siRNAs (siDKK1) $48 \mathrm{~h}$ after transfections. (b) qPCR analysis of the expression of PDGFR $\beta$, WNT-5A, c-MYC, and TGF $\beta 1$ in LX2 cells transfected with siGL or siDKK1 siRNAs $(24 \mathrm{~h})$ and then treated with TGF $\beta 1(5 \mathrm{ng} / \mathrm{mL})$ for other $24 \mathrm{~h}$ as indicated, Figure S4: Immunoblot analysis of DKK1 expression in LX2 cells treated as indicated. CM414 $(5 \mu \mathrm{M})$ was added $1 \mathrm{~h}$ before TGF $\beta 1$ $(5 \mathrm{ng} / \mathrm{mL})$ and cells were lysed for protein analyses $24 \mathrm{~h}$ later. $\alpha$-tubulin $(\alpha$-TUB) levels were analyzed as loading control. Representative blots are shown (left panel) and densitometric analyses of the immunoblots shown (right panel), Figure S5: qPCR analysis of the expression of $\alpha$-Sma, ColI $\alpha 1, P d g f r \beta$, Tenascin C, and Tnf $\alpha$ in cultured primary mouse cholangiocytes treated with TGF $\beta 1(5 \mathrm{ng} / \mathrm{mL})$ and CM414 $(5 \mu \mathrm{M})$ for $24 \mathrm{~h}$ as indicated, Figure S6: (a) immunoblot analysis of phospho-p65 (p-p65) and p65 levels in RAW264.7 cells pretreated with CM414 (5 $\mu \mathrm{M})$ for $2 \mathrm{~h}$ and then stimulated with LPS $(200 \mathrm{ng} / \mathrm{mL})$ for $15 \mathrm{~min}$. Representative blots are shown. (b) qPCR analysis of the expression of Tnf $\alpha$ in RAW264.7 cells pretreated with CM414 $(5 \mu \mathrm{M})$ for $1 \mathrm{~h}$ and then stimulated with LPS $(100 \mathrm{ng} / \mathrm{mL})$ for the indicated times.

Author Contributions: Conceptualization, A.C.-C., I.U., M.U.L., K.R., M.L.M.-C., J.M.B., J.J.G.M., C.B., J.O., M.G.F.-B. and M.A.A.; methodology, A.C.-C., L.C., I.U., M.U.L., M.A., J.M.H., L.A., K.R., C.B., M.G.F.-B. and M.A.A.; investigation, A.C.-C., L.C., M.A., C.B., M.G.F.-B. and M.A.A.; resources, J.M.U., B.S., M.L.M.-C., J.M.B., J.J.G.M., C.B., M.G.F.-B. and M.A.A.; data curation, A.C.-C., L.C., and M.G.F.-B.; writing-original draft preparation, M.G.F.-B.; writing-review and editing, A.C.-C., J.O., C.B., M.G.F.-B., and M.A.A.; supervision, M.G.F.-B. and M.A.A.; project administration, M.G.F.-B. and M.A.A.; funding acquisition, J.M.U., B.S., M.L.M.-C., J.M.B., J.J.G.M., C.B., M.G.F.-B. and M.A.A. All authors have read and agreed to the published version of the manuscript.

Funding: This research was funded by: Instituto de Salud Carlos III (ISCIII) co-financed by Fondo Europeo de Desarrollo Regional (FEDER) Una manera de hacer Europa, grant numbers: PI16/01126 (M.A.A.), PI16/00598, PI19/00819 (J.J.G.M.), PI15/01132, PI18/01075 and Miguel Servet Program CON14/00129 and CPII19/00008 (J.M.B.); Fundación Científica de la Asociación Española Contra el Cáncer (AECC Scientific Foundation), grant name: Rare Cancers 2017 (J.M.U., M.L.M.-C., J.M.B., M.G.F.-B., C.B., M.A.A.); Gobierno de Navarra Salud, grant number 58/17 (J.M.U., M.A.A.); La Caixa Foundation, grant name: HEPACARE (C.B., M.A.A.); AMMF The Cholangiocarcinoma Charity, UK, grant number: 2018/117 (M.A.A.); PSC Partners US, PSC Supports UK, grant number 06119JB (J.M.B.); Horizon 2020 (H2020) ESCALON project, grant number H2020-SC1-BHC-2018-2020 (J.M.B.); BIOEF (Basque Foundation for Innovation and Health Research: EiTB Maratoia, grant numbers BIO15/CA/016/BD (J.M.B.) and BIO15/CA/011 (M.A.A.). Department of Health of the Basque Country, grant number 2017111010 (J.M.B.), Euskadi RIS3 (grant numbers 2016222001, 2017222014, 2018222029, 2019222054, 2020333010) (J.M.B.) and Elkartek (grant number KK-2020/00008) (J.M.B.), “Junta de Castilla y Leon” grant number SA063P17 
(J.J.G.M.), La Caixa Foundation, grant number: LCF/PR/HP17/52190004 (M.L.M.-C.), FEDER/Ministerio de Ciencia, Innovacion y Universidades-Agencia Estatal de Investigación, grant numbers SAF2016-75197-R (J.J.G.M.), SAF2017-88933-R (M.G.F.-B.), SAF2017-87301-R (M.L.M.-C.), PID2019-104878RB-100 (M.A.A.) and PID2019-104265RB-100 (C.B.). Fundación BBVA grant name: Ayudas a Equipos de Investigación Científica Umbrella 2018 (M.L.M.-C.). MCIU, grant number: Severo Ochoa Excellence Accreditation SEV-2016-0644 (M.L.M.-C.), “Centro Internacional sobre el Envejecimiento” OLD-HEPAMARKER, 0348_CIE_6_E (J.J.G.M.), University of Salamanca Foundation grant number PC-TCUE18-20_051 (J.J.G.M.) and Fundació Marato TV3, grant number 201916-31 (J.J.G.M.). Gobierno de Navarra fellowship to L.C.; AECC post-doctoral fellowship to M.A.; Ramón y Cajal Program contract MICIU-AEI/RYC2018-024475-1 to M.G.F.-B. The generous support from: Fundación Eugenio Rodríguez Pascual, Fundación Mario Losantos, Fundación M Torres and Mr. Eduardo Avila are acknowledged.

Acknowledgments: The technical support of Roberto Barbero is acknowledged. This work was carried out in the framework of Working Group 5 of the COST Action CA18122, European Cholangiocarcinoma Network, EURO-CHOLANGIO-NET.

Conflicts of Interest: The authors declare no conflict of interest.

Appendix A

Table A1. List of primers sequences.

\begin{tabular}{|c|c|c|}
\hline Gene & Fw Sequence $5^{\prime}-3^{\prime}$ & Rev Sequence $5^{\prime}-3^{\prime}$ \\
\hline Ck19 (mouse) & CTCGGATTGAGGAGCTGAAC & TCACGCTCTGGATCTGTGAC \\
\hline Colla1 (mouse) & CAGATTGAGAACATCCGCAG & GAATCCATCGGTCATGCTCTC \\
\hline$H 3 f 3 a$ (mouse) & AAAGCCGCTCGCAAGAGTGCG & ACTTGCСTCCTGCAAAGCAC \\
\hline Hdac1 (mouse) & CTACTACGACGGGGATGTTGG & GAATCTCTGCATCTGCTTGCT \\
\hline Hdac2 (mouse) & GAGGGATATTGGTGCTGGAA & AAGGGCAACTGCAGTCTCAT \\
\hline Hdac3 (mouse) & GAGAGTCAGCCCCACCAATA & GACCCGGTCAGTGAGGTAGA \\
\hline Hdac6 (mouse) & GCTGACTACATTGCTGCTTTCCT & ACTCCAGCATGGGGCAAG \\
\hline Il-1 $\beta$ (mouse) & CATTGTGGCTGTGGAGAAGC & CCTTGTACAAAGCTCATGGAG \\
\hline Il-10 (mouse) & CTGCACCСАСТTCCCAG & AGAAATCGATGACAGCG \\
\hline iNos (mouse) & GTGAGGATCAAAAACTGG & TTTGCCTCTTTGAAGGAGC \\
\hline Lox (mouse) & TAGGGCGGATGTCAGAGACT & CCAGGACTCAATCCCTGTGT \\
\hline Mcp1 (mouse) & CCACTCACCTGCTGCTACTC & TTCACATTCAAAGGTGCTGAAG \\
\hline Mmp13 (mouse) & CCTGATGTGGGTGAATACAATG & GGTTTCATCATCATCAAAATGG \\
\hline Pde5 (mouse) & GAAGGGGACCAGTGCTCAAG & CCACAATGCCTTTGTTCCA \\
\hline Tenascin C (mouse) & GGATTGGTGTTTCTGCTGTCAA & TTTCAGACACCCGTAAGTCCTT \\
\hline Tgfß2 (mouse) & CAGATCCTGAGCAAGCTGAA & CTGAAGTAGGGTCTGTAGAAAGTGG \\
\hline Timp1 (mouse) & AGACCACCTTATACCAGCG & AACAGGGAAACACTGTGCA \\
\hline $\operatorname{Tnf} \alpha$ (mouse) & GAGTGACAAGCCTGTAGCCC & СССТTСТССAGCTGGAAGAC \\
\hline Wnt-5a (mouse) & GTCCTTTGAGATGGGTGGTATC & ACCTCTGGGTTAGGGAGTGTCT \\
\hline$\alpha-S M A$ (human) & CCAGGGCTGTTTTCCCATCC & GTCATTTTCTCCCGGTTGGCC \\
\hline$B A M B I$ (human) & TGGATCGCCACTCCAGCTA & TGTCTTCATGACAGCATTCCA \\
\hline$c-M Y C$ (human) & CTCAACGACAGCAGCTCGCC & CTTGAGGACCAGTGGGCTGTG \\
\hline COLI $\alpha 1$ (human) & CAGATTGAGAACATCCGCAG & GAATCCATCGGTCATGCTCTC \\
\hline DKK1 (human) & CAAAAATGTATCACACCAAAGG & TGGCTTGATGGTGATCTTTC \\
\hline DKK2 (human) & TGCCACAGTCCCCACCAA & TACAGACTTCCCCCTGATGG \\
\hline sGC $\beta 1$ (human) & GCAAGCATGCATCTGGAGAA & CCAGCAATTTCCATCATGTC \\
\hline GFAP (human) & GAGATGATGGAGCTCAATGAC & TCCAGCCTCAGGTTGGTTTC \\
\hline H3F3A (human) & AAAGCCGCTCGCAAGAGTGCG & ACTTGCCTCCTGCAAAGCAC \\
\hline IL-6 (human) & ССTTCCAAAGATGGCTGAAA & AAAGCTGCGCAGAATGAGAT \\
\hline MCP1 (human) & TCTGCCGCCCTTCTGTGCCTG & CTTCTTTGGGACACTTGCTGC \\
\hline PDGFR $\beta$ (human) & GTGATGTGGGAACAGATGTCC & GAGGAAGCCCATGGTGGGATC \\
\hline$P G C-1 \alpha$ (human) & GCTGACAGATGGAGACGTGA & GTGTGAGGAGGGTCATCGTT \\
\hline PI3K (human) & ATTGAACCAGTAGGCAACCG & GAAACTATTACCCAGATCACCAC \\
\hline$P K G$ (human) & CGCCAACCTGAAGCTGTCT & CCTTTGGAATGCAGATAGGC \\
\hline PTEN (human) & GACTTAGACTTGACCTATATTTATCC & ACTCССTTTTTGTCTCTGGTCC \\
\hline TGF 22 (human) & CAGATCCTGAGCAAGCTGAA & CTGAAGTAGGGTCTGTAGAAAGTGG \\
\hline WNT-5A (human) & GGGTGGGAACCAAGAAAAAT & TGGAACCTACCCATCCCATA \\
\hline
\end{tabular}




\section{References}

1. Trautwein, C.; Friedman, S.L.; Schuppan, D.; Pinzani, M. Hepatic fibrosis: Concept to treatment. J. Hepatol. 2015, 62, S15-S24. [CrossRef] [PubMed]

2. Lee, Y.A.; Wallace, M.C.; Friedman, S.L. Pathobiology of liver fibrosis: A translational success story. Gut 2015, 64, 830-841. [CrossRef] [PubMed]

3. Byass, P. The global burden of liver disease: A challenge for methods and for public health. BMC Med. 2014, 12, 1-3. [CrossRef] [PubMed]

4. Marcellin, P.; Kutala, B.K. Liver diseases: A major, neglected global public health problem requiring urgent actions and large-scale screening. Liver Int. 2018, 38 (Suppl. 1), 2-6. [CrossRef]

5. Asrani, S.K.; Devarbhavi, H.; Eaton, J.; Kamath, P.S. Burden of liver diseases in the world. J. Hepatol. 2019, 70, 151-171. [CrossRef]

6. Pimpin, L.; Cortez-Pinto, H.; Negro, F.; Corbould, E.; Lazarus, J.V.; Webber, L.; Sheron, N. Burden of liver disease in Europe: Epidemiology and analysis of risk factors to identify prevention policies. J. Hepatol. 2018, 69, 718-735. [CrossRef]

7. Sepanlou, S.G.; Safiri, S.; Bisignano, C.; Ikuta, K.S.; Merat, S.; Saberifiroozi, M.; Poustchi, H.; Tsoi, D.; Colombara, D.V.; Abdoli, A.; et al. The global, regional, and national burden of cirrhosis by cause in 195 countries and territories, 1990-2017: A systematic analysis for the Global Burden of Disease Study 2017. Lancet Gastroenterol. Hepatol. 2020, 5, 245-266. [CrossRef]

8. Bataller, R.; Brenner, D.A. Liver fibrosis. J. Clin. Investig. 2005, 115, 209-218. [CrossRef]

9. Berasain, C.; Avila, M.A. Regulation of hepatocyte identity and quiescence. Cell. Mol. Life Sci. 2015, 72, 3831-3851. [CrossRef]

10. Carloni, V.; Luong, T.V.; Rombouts, K. Hepatic stellate cells and extracellular matrix in hepatocellular carcinoma: More complicated than ever. Liver Int. 2014, 34, 834-843. [CrossRef]

11. Filliol, A.; Schwabe, R.F. Contributions of Fibroblasts, Extracellular Matrix, Stiffness, and Mechanosensing to Hepatocarcinogenesis. Semin. Liver Dis. 2019, 39, 315-333. [CrossRef] [PubMed]

12. Higashi, T.; Friedman, S.L.; Hoshida, Y. Hepatic stellate cells as key target in liver fibrosis. Adv. Drug Deliv. Rev. 2017, 121, 27-42. [CrossRef] [PubMed]

13. Baglieri, J.; Brenner, D.A.; Kisseleva, T. The role of fibrosis and liver-associated fibroblasts in the pathogenesis of hepatocellular carcinoma. Int. J. Mol. Sci. 2019, 20, 1723. [CrossRef] [PubMed]

14. Friedman, S.L. Mechanisms of Hepatic Fibrogenesis. Gastroenterology 2008, 134, 1655-1669. [CrossRef] [PubMed]

15. Friedman, S.L. Evolving challenges in hepatic fibrosis. Nat. Rev. Gastroenterol. Hepatol. 2010, 7, 425-436. [CrossRef] [PubMed]

16. Seki, E.; Schwabe, R.F. Hepatic inflammation and fibrosis: Functional links and key pathways. Hepatology 2015, 61, 1066-1079. [CrossRef] [PubMed]

17. Koyama, Y.; Brenner, D.A. Liver inflammation and fibrosis. J. Clin. Investig. 2017, 127, 55-64. [CrossRef]

18. Yoon, Y.J.; Friedman, S.L.; Lee, Y.A. Antifibrotic Therapies: Where Are We Now? Semin. Liver Dis. 2016, 36, 83-98. [CrossRef]

19. Lemoinne, S.; Friedman, S.L. New and emerging anti-fibrotic therapeutics entering or already in clinical trials in chronic liver diseases. Curr. Opin. Pharmacol. 2019, 49, 60-70. [CrossRef]

20. Barcena-Varela, M.; Paish, H.; Alvarez, L.; Uriarte, I.; Latasa, M.U.; Santamaria, E.; Recalde, M.; Garate, M.; Claveria, A.; Colyn, L.; et al. Epigenetic mechanisms and metabolic reprogramming in fibrogenesis: Dual targeting of G9a and DNMT1 for the inhibition of liver fibrosis. Gut 2020. [CrossRef]

21. Barcena-Varela, M.; Colyn, L.; Fernandez-Barrena, M.G. Epigenetic mechanisms in hepatic stellate cell activation during liver fibrosis and carcinogenesis. Int. J. Mol. Sci. 2019, 20, 2507. [CrossRef] [PubMed]

22. Hardy, T.; Mann, D.A. Epigenetics in liver disease: From biology to therapeutics. Gut 2016, 65, 1895-1905. [CrossRef] [PubMed]

23. Kouzarides, T. Chromatin modifications and their function. Cell 2007, 128, 693-705. [CrossRef] [PubMed]

24. Mann, J.; Mann, D. Epigenetic regulation of wound healing and fibrosis. Curr. Opin. Rheumatol. 2013, 25, 101-107. [CrossRef]

25. Eberharter, A.; Becker, P.B. Histone Acetylation: A Switch between Repressive and Permissive Chromatin. Second in Review Series on Chromatin Dynamics. EMBO Rep. 2002, 3. [CrossRef] [PubMed] 
26. Thiagalingam, S.; Cheng, K.H.; Lee, H.J.; Mineva, N.; Thiagalingam, A.; Ponte, J.F. Histone deacetylases: Unique players in shaping the epigenetic histone code. Ann. N. Y. Acad. Sci. 2003, 983, 84-100. [CrossRef] [PubMed]

27. Chen, P.-J.; Huang, C.; Meng, X.-M.; Li, J. Epigenetic modifications by histone deacetylases: Biological implications and therapeutic potential in liver fibrosis. Biochimie 2015, 116, 61-69. [CrossRef]

28. Gregoretti, I.V.; Lee, Y.M.; Goodson, H.V. Molecular evolution of the histone deacetylase family: Functional implications of phylogenetic analysis. J. Mol. Biol. 2004, 338, 17-31. [CrossRef]

29. Mannaerts, I.; Eysackers, N.; Onyema, O.O.; Van Beneden, K.; Valente, S.; Mai, A.; Odenthal, M.; van Grunsven, L.A. Class II HDAC Inhibition Hampers Hepatic Stellate Cell Activation by Induction of MicroRNA-29. PLoS ONE 2013, 8, e55786. [CrossRef]

30. Shaker, M.E.; Ghani, A.; Shiha, G.E.; Ibrahim, T.M.; Mehal, W.Z. Nilotinib induces apoptosis and autophagic cell death of activated hepatic stellate cells via inhibition of histone deacetylases. Biochim. Biophys. Acta Mol. Cell Res. 2013, 1833, 1992-2003. [CrossRef]

31. Glozak, M.A.; Sengupta, N.; Zhang, X.; Seto, E. Acetylation and deacetylation of non-histone proteins. Gene 2005, 363, 15-23. [CrossRef] [PubMed]

32. Grozinger, C.M.; Hassig, C.A.; Schreiber, S.L. Three proteins define a class of human histone deacetylases related to yeast Hda1p. Proc. Natl. Acad. Sci. USA 1999, 96, 4868-4873. [CrossRef] [PubMed]

33. Hubbert, C.; Guardiola, A.; Shao, R.; Kawaguchi, Y.; Ito, A.; Nixon, A.; Yoshida, M.; Wang, X.F.; Yao, T.P. HDAC6 is a microtubule-associated deacetylase. Nature 2002, 417, 455-458. [CrossRef] [PubMed]

34. Liu, Y.; Peng, L.; Seto, E.; Huang, S.; Qiu, Y. Modulation of histone deacetylase 6 (HDAC6) nuclear import and tubulin deacetylase activity through acetylation. J. Biol. Chem. 2012, 287, 29168-29174. [CrossRef] [PubMed]

35. Li, Y.; Shin, D.; Kwon, S.H. Histone deacetylase 6 plays a role as a distinct regulator of diverse cellular processes. FEBS J. 2013, 280, 775-793. [CrossRef] [PubMed]

36. Wang, J.; Zhao, L.; Wei, Z.; Zhang, X.; Wang, Y.; Li, F.; Fu, Y.; Liu, B. Inhibition of histone deacetylase reduces lipopolysaccharide-induced-inflammation in primary mammary epithelial cells by regulating ROS-NF-кB signaling pathways. Int. Immunopharmacol. 2018, 56, 230-234. [CrossRef]

37. Zhang, W.B.; Zhang, H.Y.; Jiao, F.Z.; Wang, L.W.; Zhang, H.; Gong, Z.J. Histone deacetylase 6 inhibitor ACY-1215 protects against experimental acute liver failure by regulating the TLR4-MAPK/NF- $\mathrm{kB}$ pathway. Biomed. Pharmacother. 2018, 97, 818-824. [CrossRef]

38. Tao, H.; Yang, J.J.; Shi, K.H.; Li, J. Epigenetic factors MeCP2 and HDAC6 control $\alpha$-tubulin acetylation in cardiac fibroblast proliferation and fibrosis. Inflamm. Res. 2016, 65, 415-426. [CrossRef]

39. Saito, S.; Zhuang, Y.; Shan, B.; Danchuk, S.; Luo, F.; Korfei, M.; Guenther, A.; Lasky, J.A. Tubastatin ameliorates pulmonary fibrosis by targeting the TGF $\beta$-PI3K-Akt pathway. PLoS ONE 2017, 12. [CrossRef]

40. Shan, B.; Yao, T.P.; Nguyen, H.T.; Zhuo, Y.; Levy, D.R.; Klingsberg, R.C.; Tao, H.; Palmer, M.L.; Holder, K.N.; Lasky, J.A. Requirement of HDAC6 for transforming growth factor- $\beta 1$-induced epithelial-mesenchymal transition. J. Biol. Chem. 2008, 283, 21065-21073. [CrossRef]

41. Yoon, S.; Kang, G.; Eom, G.H. Hdac inhibitors: Therapeutic potential in fibrosis-associated human diseases. Int. J. Mol. Sci. 2019, 20, 1329. [CrossRef] [PubMed]

42. Činčárová, L.; Zdráhal, Z.; Fajkus, J. New perspectives of valproic acid in clinical practice. Expert Opin. Investig. Drugs 2013, 22, 1535-1547. [CrossRef] [PubMed]

43. Xu, W.S.; Parmigiani, R.B.; Marks, P.A. Histone deacetylase inhibitors: Molecular mechanisms of action. Oncogene 2007, 26, 5541-5552. [CrossRef] [PubMed]

44. Ikura, Y.; Iwasa, Y.; Ueda, M. Valproic acid administration for hepatic fibrosis: A balance between antifibrotic efficacy and hepatotoxicity. Hepatology 2010, 51, 2227-2228. [CrossRef] [PubMed]

45. Ali, F.E.M.; Azouz, A.A.; Bakr, A.G.; Abo-youssef, A.M.; Hemeida, R.A.M. Hepatoprotective effects of diosmin and/or sildenafil against cholestatic liver cirrhosis: The role of Keap-1/Nrf-2 and P38-MAPK/NF-kB/iNOS signaling pathway. Food Chem. Toxicol. 2018, 120, 294-304. [CrossRef] [PubMed]

46. Mansour, H.M.; Salama, A.A.A.; Abdel-Salam, R.M.; Ahmed, N.A.; Yassen, N.N.; Zaki, H.F. The anti-inflammatory and anti-fibrotic effects of tadalafil in thioacetamide-induced liver fibrosis in rats. Can. J. Physiol. Pharmacol. 2018, 96, 1308-1317. [CrossRef] [PubMed]

47. Andersson, K.E. Mechanisms of penile erection and basis for pharmacological treatment of erectile dysfunction. Pharmacol. Rev. 2011, 63, 811-859. [CrossRef] 
48. Andersson, K.E. PDE5 inhibitors-Pharmacology and clinical applications 20 years after sildenafil discovery. Br. J. Pharmacol. 2018, 175, 2554-2565. [CrossRef]

49. Friebe, A.; Sandner, P.; Schmidtko, A. cGMP: A unique 2nd messenger molecule-Recent developments in cGMP research and development. Naunyn. Schmiedebergs. Arch. Pharmacol. 2020, 393, 287-302. [CrossRef]

50. Shah, V.; Haddad, F.G.; Garcia-Cardena, G.; Frangos, J.A.; Mennone, A.; Groszmann, R.J.; Sessa, W.C. Liver sinusoidal endothelial cells are responsible for nitric oxide modulation of resistance in the hepatic sinusoids. J. Clin. Investig. 1997, 100, 2923-2930. [CrossRef]

51. Poisson, J.; Lemoinne, S.; Boulanger, C.; Durand, F.; Moreau, R.; Valla, D.; Rautou, P.E. Liver sinusoidal endothelial cells: Physiology and role in liver diseases. J. Hepatol. 2017, 66, 212-227. [CrossRef] [PubMed]

52. Perri, R.E.; Langer, D.A.; Chatterjee, S.; Gibbons, S.J.; Gadgil, J.; Cao, S.; Farrugia, G.; Shah, V.H. Defects in cGMP-PKG pathway contribute to impaired NO-dependent responses in hepatic stellate cells upon activation. Am. J. Physiol. Gastrointest. Liver Physiol. 2006, 290. [CrossRef] [PubMed]

53. Hall, K.C.; Bernier, S.G.; Jacobson, S.; Liu, G.; Zhang, P.Y.; Sarno, R.; Catanzano, V.; Currie, M.G.; Masferrer, J.L. SGC stimulator praliciguat suppresses stellate cell fibrotic transformation and inhibits fibrosis and inflammation in models of NASH. Proc. Natl. Acad. Sci. USA 2019, 166, 11057-11062. [CrossRef] [PubMed]

54. Beyer, C.; Zenzmaier, C.; Palumbo-Zerr, K.; Mancuso, R.; Distler, A.; Dees, C.; Zerr, P.; Huang, J.; Maier, C.; Pachowsky, M.L.; et al. Stimulation of the soluble guanylate cyclase (sGC) inhibits fibrosis by blocking non-canonical TGF $\beta$ signalling. Ann. Rheum. Dis. 2015, 74, 1408-1416. [CrossRef]

55. Schinner, E.; Wetzl, V.; Schlossmann, J. Cyclic nucleotide signalling in kidney fibrosis. Int. J. Mol. Sci. 2015, 16, 2320-2351. [CrossRef] [PubMed]

56. Cuadrado-Tejedor, M.; Garcia-Barroso, C.; Sánchez-Arias, J.A.; Rabal, O.; Pérez-González, M.; Mederos, S.; Ugarte, A.; Franco, R.; Segura, V.; Perea, G.; et al. A First-in-Class Small-Molecule that Acts as a Dual Inhibitor of HDAC and PDE5 and that Rescues Hippocampal Synaptic Impairment in Alzheimer's Disease Mice. Neuropsychopharmacology 2017, 42, 524-539. [CrossRef] [PubMed]

57. Cuadrado-Tejedor, M.; Garcia-Barroso, C.; Sanzhez-Arias, J.; Mederos, S.; Rabal, O.; Ugarte, A.; Franco, R.; Pascual-Lucas, M.; Segura, V.; Perea, G.; et al. Concomitant histone deacetylase and phosphodiesterase 5 inhibition synergistically prevents the disruption in synaptic plasticity and it reverses cognitive impairment in a mouse model of Alzheimer's disease. Clin. Epigenetics 2015. [CrossRef]

58. Rabal, O.; Sánchez-Arias, J.A.; Cuadrado-Tejedor, M.; De Miguel, I.; Pérez-González, M.; García-Barroso, C.; Ugarte, A.; Estella-Hermoso De Mendoza, A.; Sáez, E.; Espelosin, M.; et al. Design, Synthesis, and Biological Evaluation of First-in-Class Dual Acting Histone Deacetylases (HDACs) and Phosphodiesterase 5 (PDE5) Inhibitors for the Treatment of Alzheimer's Disease. J. Med. Chem. 2016, 59, 8967-9004. [CrossRef]

59. Fickert, P.; Fuchsbichler, A.; Wagner, M.; Zollner, G.; Kaser, A.; Tilg, H.; Krause, R.; Lammert, F.; Langner, C.; Zatloukal, K.; et al. Regurgitation of bile acids from leaky bile ducts causes sclerosing cholangitis in Mdr2 (Abcb4) knockout mice. Gastroenterology 2004, 127, 261-274. [CrossRef]

60. Nakken, K.E.; Nygård, S.; Haaland, T.; Berge, K.E.; Arnkværn, K.; Ødegaard, A.; Labori, K.J.; Ræder, M.G. Multiple inflammatory-, tissue remodelling- and fibrosis genes are differentially transcribed in the livers of Abcb4 (-/-) mice harbouring chronic cholangitis. Scand. J. Gastroenterol. 2007, 42, 1245-1255. [CrossRef]

61. Mauad, T.H.; Van Nieuwkerk, C.M.J.; Dingemans, K.P.; Smit, J.J.M.; Schinkel, A.H.; Notenboom, R.G.E.; Van den Bergh Weerman, M.A.; Verkruisen, R.P.; Groen, A.K.; Elferink, R.P.J.O.; et al. Mice with homozygous disruption of the mdr2 P-glycoprotein gene: A novel animal model for studies of nonsuppurative inflammatory cholangitis and hepatocarcinogenesis. Am. J. Pathol. 1994, 145, 1237-1245. [PubMed]

62. Nishio, T.; Hu, R.; Koyama, Y.; Liang, S.; Rosenthal, S.B.; Yamamoto, G.; Karin, D.; Baglieri, J.; Ma, H.Y.; Xu, J.; et al. Activated hepatic stellate cells and portal fibroblasts contribute to cholestatic liver fibrosis in MDR2 knockout mice. J. Hepatol. 2019, 71, 573-585. [CrossRef] [PubMed]

63. Pikarsky, E.; Porat, R.M.; Stein, I.; Abramovitch, R.; Amit, S.; Kasem, S.; Gutkovich-Pyest, E.; Uriell-Shoval, S.; Galun, E.; Ben-Neriah, Y. NF-kB functions as a tumour promoter in inflammation-associated cancer. Nature 2004, 431, 461-466. [CrossRef] [PubMed]

64. Popov, Y.; Patsenker, E.; Fickert, P.; Trauner, M.; Schuppan, D. Mdr2 (Abcb4)-/- mice spontaneously develop severe biliary fibrosis via massive dysregulation of pro- and antifibrogenic genes. J. Hepatol. 2005, 43, 1045-1054. [CrossRef] 
65. Latasa, M.U.; Gil-Puig, C.; Fernández-Barrena, M.G.; Rodríguez-Ortigosa, C.M.; Banales, J.M.; Urtasun, R.; Goñi, S.; Méndez, M.; Arcelus, S.; Juanarena, N.; et al. Oral methylthioadenosine administration attenuates fibrosis and chronic liver disease progression in Mdr2-/- mice. PLoS ONE 2010, 5, e15690. [CrossRef]

66. Yavuz, B.G.; Pestana, R.C.; Abugabal, Y.I.; Krishnan, S.; Chen, J.; Hassan, M.M.; Wolff, R.A.; Rashid, A.; Amin, H.M.; Kaseb, A.O. Origin and role of hepatic myofibroblasts in hepatocellular carcinoma. Oncotarget 2020, 11, 1186-1201. [CrossRef]

67. McDaniel, K.; Wu, N.; Zhou, T.; Huang, L.; Sato, K.; Venter, J.; Ceci, L.; Chen, D.; Ramos-Lorenzo, S.; Invernizzi, P.; et al. Amelioration of Ductular Reaction by Stem Cell Derived Extracellular Vesicles in MDR2 Knockout Mice via Lethal-7 microRNA. Hepatology 2019, 69, 2562-2578. [CrossRef]

68. Dropmann, A.; Dooley, S.; Dewidar, B.; Hammad, S.; Dediulia, T.; Werle, J.; Hartwig, V.; Ghafoory, S.; Woelfl, S.; Korhonen, H.; et al. TGF- $\beta 2$ silencing to target biliary-derived liver diseases. Gut 2020. [CrossRef]

69. Midwood, K.S.; Hussenet, T.; Langlois, B.; Orend, G. Advances in tenascin-C biology. Cell. Mol. Life Sci. 2011, 68, 3175-3199. [CrossRef]

70. Mohs, A.; Kuttkat, N.; Reißing, J.; Zimmermann, H.W.; Sonntag, R.; Proudfoot, A.; Youssef, S.A.; de Bruin, A.; Cubero, F.J.; Trautwein, C. Functional role of CCL5/RANTES for HCC progression during chronic liver disease. J. Hepatol. 2017, 66, 743-753. [CrossRef]

71. Xu, L.; Hui, A.Y.; Albanis, E.; Arthur, M.J.; O’Byrne, S.M.; Blaner, W.S.; Mukherjee, P.; Friedman, S.L.; Eng, F.J. Human hepatic stellate cell lines, LX-1 and LX-2: New tools for analysis of hepatic fibrosis. Gut 2005, 54, 142-151. [CrossRef] [PubMed]

72. Tabibian, J.H.; Trussoni, C.E.; O’Hara, S.P.; Splinter, P.L.; Heimbach, J.K.; LaRusso, N.F. Characterization of cultured cholangiocytes isolated from livers of patients with primary sclerosing cholangitis. Lab. Investig. 2014, 94, 1126-1133. [CrossRef] [PubMed]

73. Ørstavik, S.; Natarajan, V.; Taskén, K.; Jahnsen, T.; Sandberg, M. Characterization of the human gene encoding the type $\mathrm{I} \alpha$ and type I $\beta$ cGMP-dependent protein kinase (PRKG1). Genomics 1997, 42, 311-318. [CrossRef] [PubMed]

74. Lincoln, T.M.; Cornwell, T.L. Intracellular cyclic GMP receptor proteins. FASEB J. 1993, 7, 328-338. [CrossRef]

75. Chettimada, S.; Rawat, D.K.; Dey, N.; Kobelja, R.; Simms, Z.; Wolin, M.S.; Lincoln, T.M.; Gupte, S.A. Glc-6-PD and PKG contribute to hypoxia-induced decrease in smooth muscle cell contractile phenotype proteins in pulmonary artery. Am. J. Physiol. Lung Cell. Mol. Physiol. 2012, 303. [CrossRef]

76. Franko, A.; Kovarova, M.; Feil, S.; Feil, R.; Wagner, R.; Heni, M.; Königsrainer, A.; Ruoß, M.; Nüssler, A.K.; Weigert, C.; et al. cGMP-dependent protein kinase I (cGKI) modulates human hepatic stellate cell activation. Metabolism 2018, 88, 22-30. [CrossRef]

77. Jones, D.L.; Haak, A.J.; Caporarello, N.; Choi, K.M.; Ye, Z.; Yan, H.; Varelas, X.; Ordog, T.; Ligresti, G.; Tschumperlin, D.J. TGF $\beta$-induced fibroblast activation requires persistent and targeted HDAC-mediated gene repression. J. Cell Sci. 2019, 132. [CrossRef]

78. Palumbo-Zerr, K.; Zerr, P.; Distler, A.; Fliehr, J.; Mancuso, R.; Huang, J.; Mielenz, D.; Tomcik, M.; Fürnrohr, B.G.; Scholtysek, C.; et al. Orphan nuclear receptor NR4A1 regulates transforming growth factor- $\beta 2$ signaling and fibrosis. Nat. Med. 2015, 21, 150-158. [CrossRef]

79. Ligresti, G.; Caporarello, N.; Meridew, J.A.; Jones, D.L.; Tan, Q.; Choi, K.M.; Haak, A.J.; Aravamudhan, A.; Roden, A.C.; Prakash, Y.S.; et al. CBX5/G9a/H3K9me-mediated gene repression is essential to fibroblast activation during lung fibrosis. JCI Insight 2019, 4. [CrossRef]

80. Zhang, Q.; Xiang, S.; Liu, Q.; Gu, T.; Yao, Y.; Lu, X. PPAR $\gamma$ Antagonizes Hypoxia-Induced Activation of Hepatic Stellate Cell Through Cross Mediating PI3K/AKT and cGMP/PKG Signaling. PPAR Res. 2018, 2018. [CrossRef]

81. Kumar, P.; Raeman, R.; Chopyk, D.M.; Smith, T.; Verma, K.; Liu, Y.; Anania, F.A. Adiponectin inhibits hepatic stellate cell activation by targeting the PTEN/AKT pathway. Biochim. Biophys. Acta Mol. Basis Dis. 2018, 1864, 3537-3545. [CrossRef] [PubMed]

82. Conte, E.; Fruciano, M.; Fagone, E.; Gili, E.; Caraci, F.; Iemmolo, M.; Crimi, N.; Vancheri, C. Inhibition of PI3K prevents the proliferation and differentiation of human lung fibroblasts into myofibroblasts: The role of class I P110 isoforms. PLoS ONE 2011, 6. [CrossRef] [PubMed]

83. Conte, E.; Gili, E.; Fruciano, M.; Korfei, M.; Fagone, E.; Iemmolo, M.; Lo Furno, D.; Giuffrida, R.; Crimi, N.; Guenther, A.; et al. PI3K p110 $\gamma$ overexpression in idiopathic pulmonary fibrosis lung tissue and fibroblast cells: In vitro effects of its inhibition. Lab. Investig. 2013, 93, 566-576. [CrossRef] [PubMed] 
84. Kawano, Y.; Kypta, R. Secreted antagonists of the Wnt signalling pathway. J. Cell Sci. 2003, 116, $2627-2634$. [CrossRef] [PubMed]

85. Akhmetshina, A.; Palumbo, K.; Dees, C.; Bergmann, C.; Venalis, P.; Zerr, P.; Horn, A.; Kireva, T.; Beyer, C.; Zwerina, J.; et al. Activation of canonical Wnt signalling is required for TGF- $\beta$-mediated fibrosis. Nat. Commun. 2012, 3. [CrossRef]

86. Xiong, W.-J.; Hu, L.-J.; Jian, Y.-C.; Wang, L.-J.; Jiang, M.; Li, W.; He, Y. Wnt5a participates in hepatic stellate cell activation observed by gene expression profile and functional assays. World J. Gastroenterol. 2012, 18, 1745. [CrossRef]

87. Beljaars, L.; Daliri, S.; Dijkhuizen, C.; Poelstra, K.; Gosens, R. WNT-5A regulates TGF- $\beta$-related activities in liver fibrosis. Am. J. Physiol. Gastrointest. Liver Physiol. 2017, 312, G219-G227. [CrossRef]

88. Jones, H.; Hargrove, L.; Kennedy, L.; Meng, F.; Graf-Eaton, A.; Owens, J.; Alpini, G.; Johnson, C.; Bernuzzi, F.; Demieville, J.; et al. Inhibition of mast cell-secreted histamine decreases biliary proliferation and fibrosis in primary sclerosing cholangitis Mdr2-/- mice. Hepatology 2016, 64, 1202-1216. [CrossRef]

89. Fabris, L.; Brivio, S.; Cadamuro, M.; Strazzabosco, M. Revisiting Epithelial-to-Mesenchymal Transition in Liver Fibrosis: Clues for a Better Understanding of the "Reactive" Biliary Epithelial Phenotype. Stem Cells Int. 2016, 2016. [CrossRef]

90. Greenbaum, L.E.; Wells, R.G. The role of stem cells in liver repair and fibrosis. Int. J. Biochem. Cell Biol. 2011, 43, 222-229. [CrossRef]

91. Doyle, S.L.; O'Neill, L.A.J. Toll-like receptors: From the discovery of NFKB to new insights into transcriptional regulations in innate immunity. Biochem. Pharmacol. 2006, 72, 1102-1113. [CrossRef] [PubMed]

92. Hussain, S.P.; Hofseth, L.J.; Harris, C.C. Radical causes of cancer. Nat. Rev. Cancer 2003, 3, 276-285. [CrossRef] [PubMed]

93. Nakamoto, Y.; Guidotti, L.G.; Kuhlen, C.V.; Fowler, P.; Chisari, F.V. Immune pathogenesis of hepatocellular carcinoma. J. Exp. Med. 1998, 188, 341-350. [CrossRef] [PubMed]

94. Erstad, D.J.; Razavi, A.A.; Li, S.; Tanabe, K.K.; Fuchs, B.C. Prevention Strategies for Hepatocellular Carcinoma. In Hepatocellular Carcinoma; Humana Press: Totowa, NJ, USA, 2019; pp. 255-289.

95. Yamauchi, M.; Mizuhara, Y.; Maezawa, Y.; Toda, G. Serum tenascin levels in chronic liver disease. Liver 1994, 14, 148-153. [CrossRef]

96. Benbow, J.H.; Thompson, K.J.; Cope, H.L.; Brandon-Warner, E.; Culberson, C.R.; Bossi, K.L.; Li, T.; Russo, M.W.; Gersin, K.S.; McKillop, I.H.; et al. Diet-Induced Obesity Enhances Progression of Hepatocellular Carcinoma through Tenascin-C/Toll-Like Receptor 4 Signaling. Am. J. Pathol. 2016, 186, 145-158. [CrossRef]

97. Boege, Y.; Malehmir, M.; Healy, M.E.; Bettermann, K.; Lorentzen, A.; Vucur, M.; Ahuja, A.K.; Böhm, F.; Mertens, J.C.; Shimizu, Y.; et al. A Dual Role of Caspase-8 in Triggering and Sensing Proliferation-Associated DNA Damage, a Key Determinant of Liver Cancer Development. Cancer Cell 2017, 32, 342-359.e10. [CrossRef]

98. Brusilovskaya, K.; Königshofer, P.; Lampach, D.; Szodl, A.; Supper, P.; Bauer, D.; Beer, A.; Stift, J.; Timelthaler, G.; Oberhuber, G.; et al. Soluble guanylyl cyclase stimulation and phosphodiesterase- 5 inhibition improve portal hypertension and reduce liver fibrosis in bile duct-ligated rats. United Eur. Gastroenterol. J. 2020. [CrossRef]

99. Guixé-Muntet, S.; Zhu, C.P.; Xie, W.F.; Gracia-Sancho, J. Novel therapeutics for portal hypertension and fibrosis in chronic liver disease. Pharmacol. Ther. 2020, 215, 107626. [CrossRef]

100. Lechuga, C.G.; Hernández-Nazara, Z.H.; Domínguez Rosales, J.A.; Morris, E.R.; Rincón, A.R.; Rivas-Estilla, A.M.; Esteban-Gamboa, A.; Rojkind, M. TGF- $\beta 1$ modulates matrix metalloproteinase-13 expression in hepatic stellate cells by complex mechanisms involving p38MAPK, PI3-kinase, AKT, and p70S6k. Am. J. Physiol. Gastrointest. Liver Physiol. 2004, 287. [CrossRef]

101. Reif, S.; Lang, A.; Lindquist, J.N.; Yata, Y.; Gäbele, E.; Scanga, A.; Brenner, D.A.; Rippe, R.A. The role of focal adhesion kinase-phosphatidylinositol 3-kinase-Akt signaling in hepatic stellate cell proliferation and type I collagen expression. J. Biol. Chem. 2003, 278, 8083-8090. [CrossRef]

102. Parsons, C.J.; Takashima, M.; Rippe, R.A. Molecular mechanisms of hepatic fibrogenesis. J. Gastroenterol. Hepatol. 2007, 22, S79-S84. [CrossRef] [PubMed]

103. Liu, Y.; Wang, Z.; Wang, J.; Lam, W.; Kwong, S.; Li, F.; Friedman, S.L.; Zhou, S.; Ren, Q.; Xu, Z.; et al. A histone deacetylase inhibitor, largazole, decreases liver fibrosis and angiogenesis by inhibiting transforming growth factor- $\beta$ and vascular endothelial growth factor signalling. Liver Int. 2013, 33, 504-515. [CrossRef] [PubMed]

104. Sotolongo, A.; Mónica, F.Z.; Kots, A.; Xiao, H.; Liu, J.; Seto, E.; Bian, K.; Murad, F. Epigenetic regulation of soluble guanylate cyclase (sGC) $\beta 1$ in breast cancer cells. FASEB J. 2016, 30, 3171-3180. [CrossRef] [PubMed] 
105. Wang, Y.; Krämer, S.; Loof, T.; Martini, S.; Kron, S.; Kawachi, H.; Shimizu, F.; Neumayer, H.H.; Peters, H. Enhancing CGMP in experimental progressive renal fibrosis: Soluble guanylate cyclase stimulation vs. phosphodiesterase inhibition. Am. J. Physiol. Ren. Physiol. 2006, 290. [CrossRef]

106. Matei, A.E.; Beyer, C.; Györfi, A.H.; Soare, A.; Chen, C.W.; Dees, C.; Bergmann, C.; Ramming, A.; Friebe, A.; Hofmann, F.; et al. Protein kinases G are essential downstream mediators of the antifibrotic effects of sGC stimulators. Ann. Rheum. Dis. 2018, 77, 459. [CrossRef]

107. Liu, C.; Chen, X.; Yang, L.; Kisseleva, T.; Brenner, D.A.; Seki, E. Transcriptional repression of the transforming growth factor $\beta$ (TGF- $\beta$ ) pseudoreceptor BMP and activin membrane-bound inhibitor (BAMBI) by nuclear factor $\kappa \mathrm{B}(\mathrm{NF}-\kappa \mathrm{B})$ p50 enhances TGF- $\beta$ signaling in hepatic stellate cells. J. Biol. Chem. 2014, 289, 7082-7091. [CrossRef]

108. Miao, C.; Yang, Y.; He, X.; Huang, C.; Huang, Y.; Zhang, L.; Lv, X.-W.; Jin, Y.; Li, J. Wnt signaling in liver fibrosis: Progress, challenges and potential directions. Biochimie 2013, 95, 2326-2335. [CrossRef]

109. Yang, Y.; Chen, X.X.; Li, W.X.; Wu, X.Q.; Huang, C.; Xie, J.; Zhao, Y.X.; Meng, X.M.; Li, J. EZH2-mediated repression of Dkk1 promotes hepatic stellate cell activation and hepatic fibrosis. J. Cell. Mol. Med. 2017, 21, 2317-2328. [CrossRef]

110. Zhao, Y.L.; Zhu, R.T.; Sun, Y.L. Epithelial-mesenchymal transition in liver fibrosis (Review). Biomed. Rep. 2016, 4, 269-274. [CrossRef]

111. Lei, W.; Zhang, K.; Pan, X.; Hu, Y.; Wang, D.; Yuan, X.; Shu, G.; Song, J. Histone deacetylase 1 is required for transforming growth factor- $\beta 1$-induced epithelial-mesenchymal transition. Int. J. Biochem. Cell Biol. 2010, 42, 1489-1497. [CrossRef]

112. Gu, S.; Liu, Y.; Zhu, B.; Ding, K.; Yao, T.P.; Chen, F.; Zhan, L.; Xu, P.; Ehrlich, M.; Liang, T.; et al. Loss of $\alpha$-tubulin acetylation is associated with TGF- $\beta$-induced epithelial-mesenchymal transition. J. Biol. Chem. 2016, 291, 5396-5405. [CrossRef] [PubMed]

113. Liu, R.; Li, X.; Zhu, W.; Wang, Y.; Zhao, D.; Wang, X.; Gurley, E.C.; Liang, G.; Chen, W.; Lai, G.; et al. Cholangiocyte-Derived Exosomal Long Noncoding RNA H19 Promotes Hepatic Stellate Cell Activation and Cholestatic Liver Fibrosis. Hepatology 2019, 70, 1317-1335. [CrossRef] [PubMed]

114. Omenetti, A.; Porrello, A.; Jung, Y.; Yang, L.; Popov, Y.; Choi, S.S.; Witek, R.P.; Alpini, G.; Venter, J.; Vandongen, H.M.; et al. Hedgehog signaling regulates epithelial-mesenchymal transition during biliary fibrosis in rodents and humans. J. Clin. Investig. 2008, 118, 3331-3342. [CrossRef] [PubMed]

115. EE, H.; MR, M.; KJ, L. HDAC Inhibitors as Epigenetic Regulators of the Immune System: Impacts on Cancer Therapy and Inflammatory Diseases. Biomed Res. Int. 2016, 2016. [CrossRef]

116. Elizalde, M.; Urtasun, R.; Azkona, M.; Latasa, M.U.; Goñi, S.; García-Irigoyen, O.; Uriarte, I.; Segura, V.; Collantes, M.; Di Scala, M.; et al. Splicing regulator SLU7 is essential for maintaining liver homeostasis. J. Clin. Investig. 2014. [CrossRef]

117. Bárcena-Varela, M.; Caruso, S.; Llerena, S.; Álvarez-Sola, G.; Uriarte, I.; Latasa, M.U.; Urtasun, R.; Rebouissou, S.; Alvarez, L.; Jimenez, M.; et al. Dual Targeting of Histone Methyltransferase G9a and DNA-Methyltransferase 1 for the Treatment of Experimental Hepatocellular Carcinoma. Hepatology 2019, 69, 587-603. [CrossRef]

118. Garcia-Irigoyen, O.; Carotti, S.; Latasa, M.U.; Uriarte, I.; Fernández-Barrena, M.G.; Elizalde, M.; Urtasun, R.; Vespasiani-Gentilucci, U.; Morini, S.; Banales, J.M.; et al. Matrix metalloproteinase-10 expression is induced during hepatic injury and plays a fundamental role in liver tissue repair. Liver Int. 2013. [CrossRef]

119. Santamaría, E.; Rodríguez-Ortigosa, C.M.; Uriarte, I.; Latasa, M.U.; Urtasun, R.; Alvarez-Sola, G.; Bárcena-Varela, M.; Colyn, L.; Arcelus, S.; Jiménez, M.; et al. The Epidermal Growth Factor Receptor Ligand Amphiregulin Protects From Cholestatic Liver Injury and Regulates Bile Acids Synthesis. Hepatology 2019, 69, 1632-1647. [CrossRef]

120. Schneider, C.A.; Rasband, W.S.; Eliceiri, K.W. NIH Image to ImageJ: 25 years of image analysis. Nat. Methods 2012, 9, 671-675. [CrossRef]

121. Uriarte, I.; Banales, J.M.; Śaez, E.; Arenas, F.; Elferink, R.P.J.O.; Prieto, J.; Medina, J.F. Bicarbonate secretion of mouse cholangiocytes involves na-hco3 cotransport in addition to na-independent $\mathrm{cl} / \mathrm{hco} 3$ exchange. Hepatology 2010, 51, 891-902. [CrossRef] 
122. Salter, K.D.; Roman, R.M.; Larusso, N.R.; Fitz, J.G.; Doctor, R.B. Modified culture conditions enhance expression of differentiated phenotypic properties of normal rat cholangiocytes. Lab. Investig. 2000, 80, 1775-1778. [CrossRef] [PubMed]

123. Rodriguez-Collazo, P.; Leuba, S.H.; Zlatanova, J. Robust methods for purification of histones from cultured mammalian cells with the preservation of their native modifications. Nucleic Acids Res. 2009, 37, e81. [CrossRef] [PubMed]

Publisher's Note: MDPI stays neutral with regard to jurisdictional claims in published maps and institutional affiliations.

(C) 2020 by the authors. Licensee MDPI, Basel, Switzerland. This article is an open access article distributed under the terms and conditions of the Creative Commons Attribution (CC BY) license (http://creativecommons.org/licenses/by/4.0/). 